\title{
ॠUSGS
}

science for a changing world

\section{Water Temperatures in Select Nearshore Environments of the Colorado River in Grand Canyon, Arizona, During the Low Steady Summer Flow Experiment of 2000}

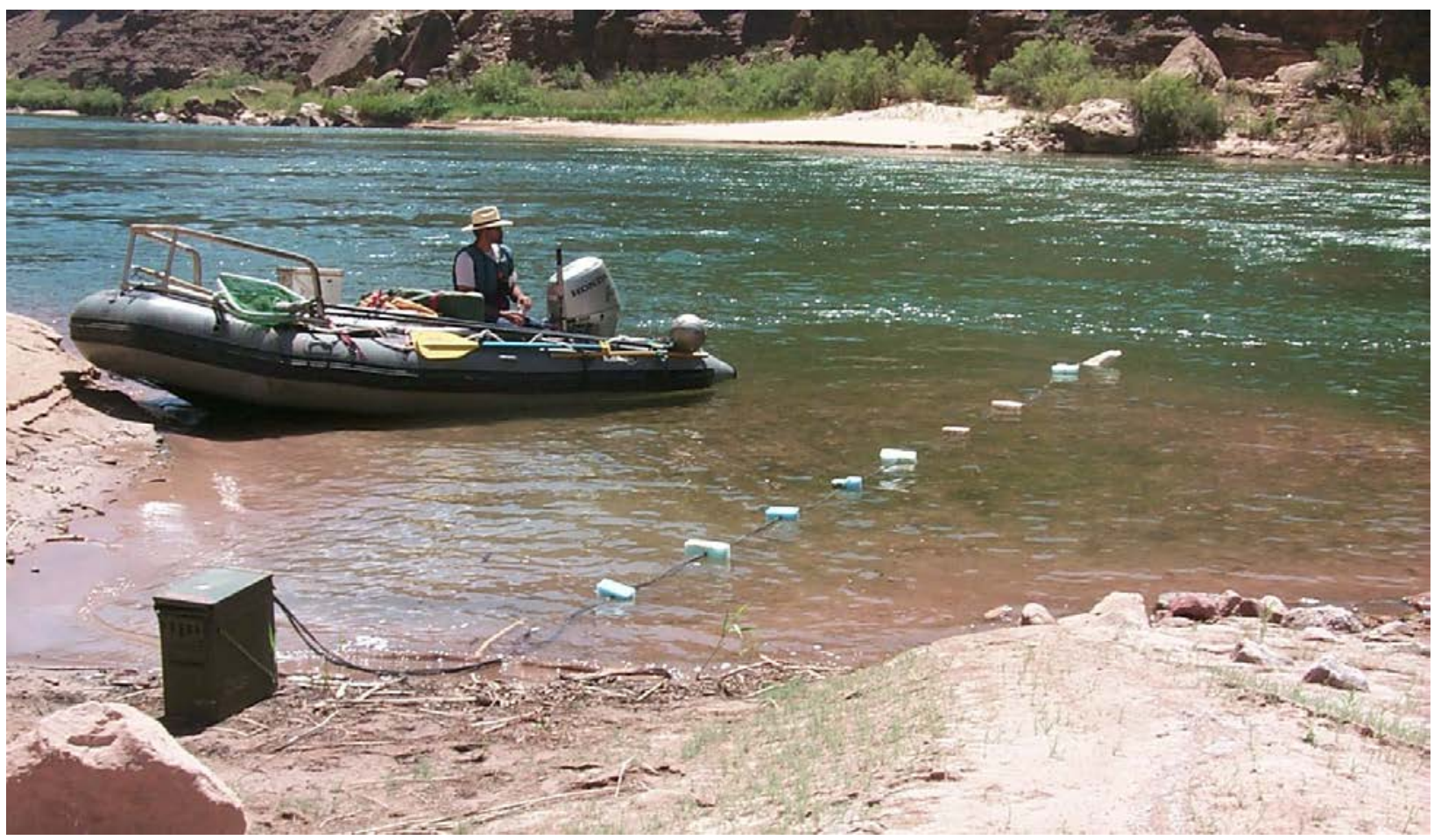

Open-File Report 2013-1066 
Photograph of thermistor-string deployment for determination of nearshore temperatures in the Colorado River in Grand Canyon during the Low Steady Summer Flow experiment of 2000 (U.S. Geological Survey photograph by William S. Vernieu). 


\section{Water Temperatures in Select Nearshore Environments of the Colorado River in Grand Canyon, Arizona, During the Low Steady Summer Flow Experiment of 2000}

By William S. Vernieu and Craig R. Anderson

Open-File Report 2013-1066 


\section{U.S. Department of the Interior \\ KEN SALAZAR, Secretary}

\section{U.S. Geological Survey \\ Suzette M. Kimball, Acting Director}

U.S. Geological Survey, Reston, Virginia: 2013

For product and ordering information:

World Wide Web: http://www.usgs.gov/pubprod

Telephone: 1-888-ASK-USGS

For more information on the USGS-the Federal source for science about the Earth,

its natural and living resources, natural hazards, and the environment:

World Wide Web: http://www.usgs.gov

Telephone: 1-888-ASK-USGS

Suggested citation:

Vernieu, W.S., and Anderson, C.R., 2013, Water temperatures in select nearshore environments of the Colorado River in Grand Canyon, Arizona, during the Low Steady Summer Flow experiment of 2000: U.S. Geological Survey OpenFile Report 2013-1066, 44 p.

Any use of trade, product, or firm names is for descriptive purposes only and does not imply endorsement by the U.S. Government.

Although this report is in the public domain, permission must be secured from the individual copyright owners to reproduce any copyrighted material contained within this report. 


\section{Contents}

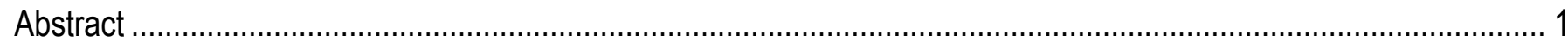

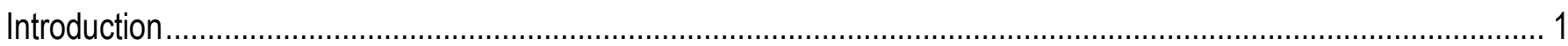

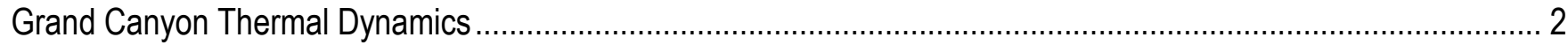

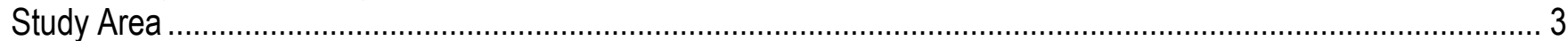

The Low Steady Summer Flow Experiment ......................................................................................... 3

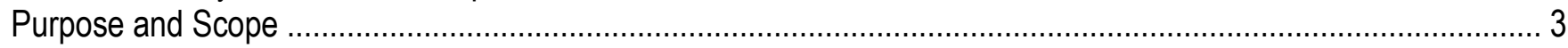

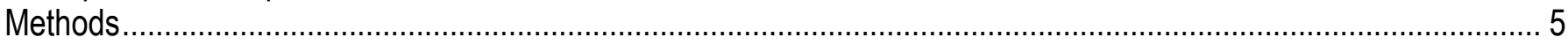

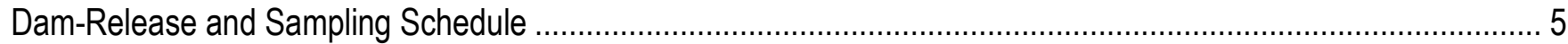

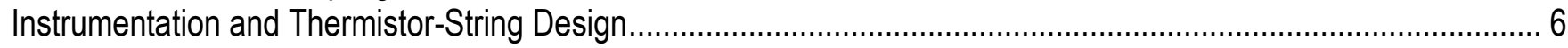

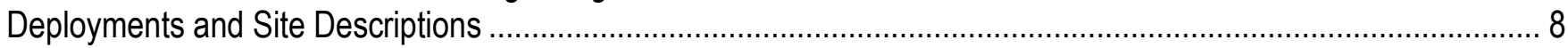

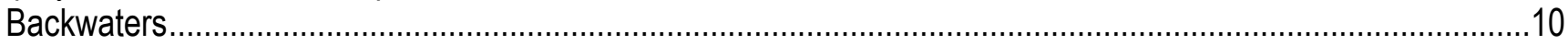

RK 141.6R

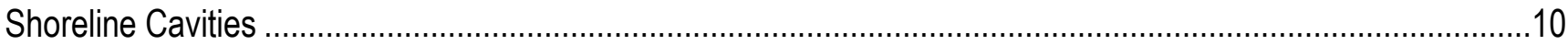

RK 104.6L

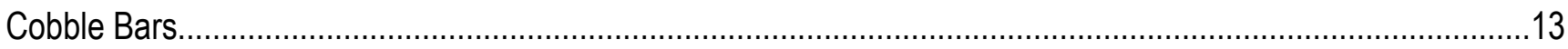

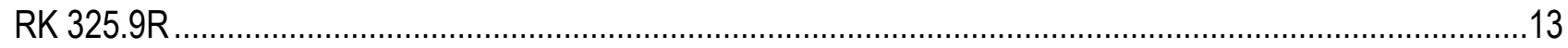

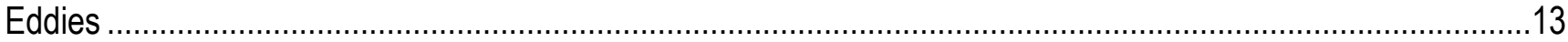

RK 102.2L

RK 141.1L

RK 141.3L

RK 221.3L

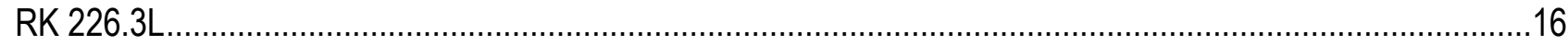

RK 231.3L

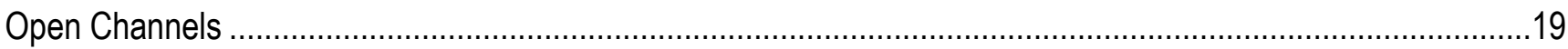

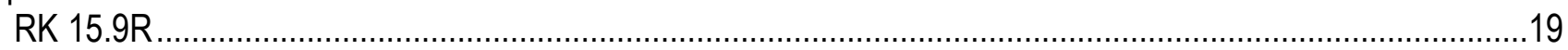

RK 416.2L

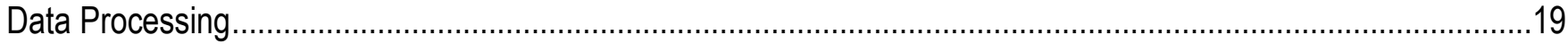

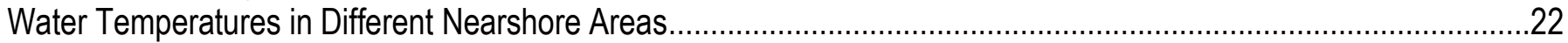

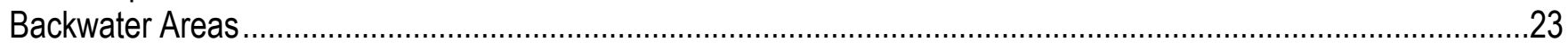

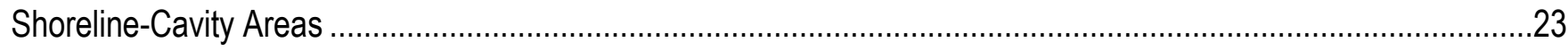

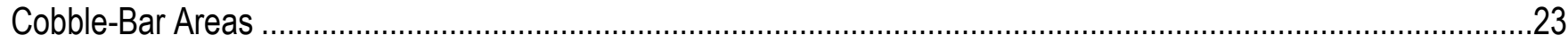

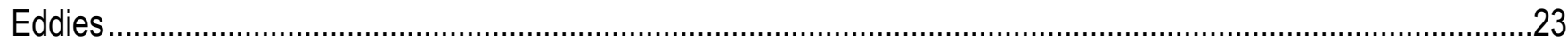

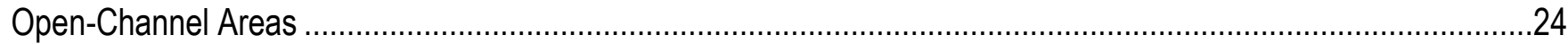

Differences in Warming Among Sites..........................................................................................................

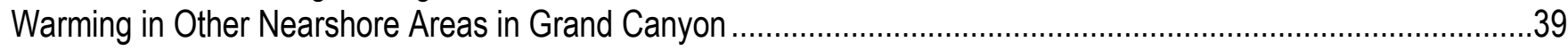

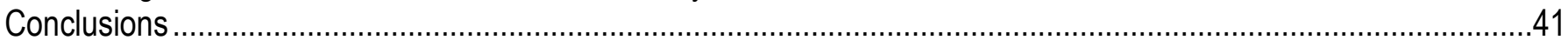

Acknowledgments …………………………………

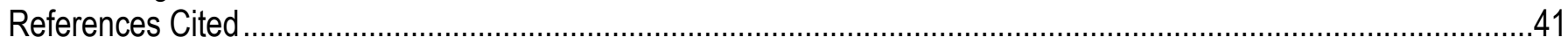




\section{Figures}

1. Map of the Colorado River and its tributaries between Lake Powell and Lake Mead, northern Arizona, showing nearshore water-temperature study sites described in this report

2. Graph showing hourly Glen Canyon Dam discharge from March 1 through October 31, 2000, including the Low Steady Summer Flow experiment from March 25 through September 30, 2000

3. Schematic diagram of thermistor-string deployment for determination of nearshore temperatures in the Colorado River in Grand Canyon during the Low Steady Summer Flow experiment of 2000.

4. Photographs of the backwater site RK 141.6R and the 25-meter thermistor-string deployment for determination of nearshore temperatures in the Colorado River in Grand Canyon during the Low Steady Summer Flow experiment of 2000 looking upstream and downstream

5. Photographs of the shoreline cavity site RK 104.6L and the 10-meter thermistor-string deployment for determination of nearshore temperatures in the Colorado River in Grand Canyon during the Low Steady Summer Flow experiment of 2000 looking upstream and across the channel.

6. Photographs of the cobble-bar site RK 325.9R and the 5-meter and 10-meter thermistor-string deployments and the 25-meter thermistor string deployed longitudinally for determination of nearshore temperatures in the Colorado River in Grand Canyon during the Low Steady Summer Flow experiment of 2000

7. Photograph of the eddy site RK 102.2L and the 25-meter thermistor-string deployment for determination of nearshore temperatures in the Colorado River in Grand Canyon during the Low Steady Summer Flow experiment of 2000 looking slightly downstream from the middle of the main channel.

8. Photograph of the eddy site RK 141.1L and the 5-meter thermistor-string deployment for determination of nearshore temperatures in the Colorado River in Grand Canyon during the Low Steady Summer Flow experiment of 2000 looking upstream toward Cremation Camp (near Phantom Ranch).....

9. Photographs of the eddy site RK 141.3L and the 5-meter thermistor-string deployment for determination of nearshore temperatures in the Colorado River in Grand Canyon during the Low Steady Summer Flow experiment of 2000 looking upstream from the main channel and shoreward from the main channel.

10. Photograph of the eddy site RK 226.3L and the 10-meter thermistor-string deployment for determination of nearshore temperatures in the Colorado River in Grand Canyon during the Low Steady Summer Flow experiment of 2000.

11. Photograph of the eddy site RK 231.3L looking upstream and the 5-meter thermistor-string deployment for determination of nearshore temperatures in the Colorado River in Grand Canyon during the Low Steady Summer Flow experiment of 2000.

12. Photographs of the open-channel site RK $-15.9 \mathrm{R}$ and the 15-meter thermistor-string deployment for determination of nearshore temperatures in the Colorado River in Grand Canyon during the Low Steady Summer Flow experiment of 2000 looking from and toward Duck Island.

13. Photographs of the open-channel site RK 416.2L and the 15-meter thermistor-string deployment for determination of nearshore temperatures in the Colorado River in Grand Canyon during the Low Steady Summer Flow experiment of 2000 looking shoreward from the main channel and from the shoreline

14. Graphs showing lateral water-temperature patterns and differences from mainstem temperature for the backwater site RK 141.6R along the Colorado River in Grand Canyon during the Low Steady Summer Flow experiment of 2000 . 
15. Graphs showing lateral water temperature patterns and differences from mainstem temperature for the shoreline cavity site RK 104.6L along the Colorado River in Grand Canyon during the Low Steady Summer Flow experiment of 2000.

16. Graphs showing lateral water-temperature patterns and differences from mainstem temperature for the cobble-bar upper site RK 325.9R along the Colorado River in Grand Canyon during the Low Steady Summer Flow experiment of 2000.

17. Graphs showing lateral water-temperature patterns and differences from mainstem temperature for the cobble-bar lower site RK 325.9R along the Colorado River in Grand Canyon during the Low Steady Summer Flow experiment of 2000 .

18. Graphs showing lateral water-temperature patterns and differences from mainstem temperature for the cobble-bar longitudinal site RK 325.9R along the Colorado River in Grand Canyon during the Low Steady Summer Flow experiment of 2000.

19. Graphs showing lateral water-temperature patterns and differences from mainstem temperature for the eddy site RK 102.2L along the Colorado River in Grand Canyon during the Low Steady Summer Flow experiment of 2000

20. Graphs showing lateral water-temperature patterns and differences from mainstem temperature for the eddy site RK 141.1L along the Colorado River in Grand Canyon during the Low Steady Summer Flow experiment of 2000

21. Graphs showing lateral water-temperature patterns and differences from mainstem temperature for the eddy site RK 141.3L along the Colorado River in Grand Canyon during the Low Steady Summer Flow experiment of 2000

22. Lateral water-temperature patterns and differences from mainstem temperature for the upper eddy site RK 221.3L along the Colorado River in Grand Canyon during the Low Steady Summer Flow experiment of 2000

23. Graphs showing lateral water-temperature patterns and differences from mainstem temperature for the lower eddy site RK 221.3L along the Colorado River in Grand Canyon during the Low Steady Summer Flow experiment of 2000.

24. Graphs showing lateral water-temperature patterns and differences from mainstem temperature for the eddy site RK 226.3L along the Colorado River in Grand Canyon during the Low Steady Summer Flow experiment of 2000

25. Graphs showing lateral water-temperature patterns and differences from mainstem temperature for the eddy site RK 231.3L along the Colorado River in Grand Canyon during the Low Steady Summer Flow experiment of 2000

26. Graphs showing lateral water-temperature patterns and differences from mainstem temperature for the open-channel site RK -15.9R along the Colorado River in Grand Canyon during the Low Steady Summer Flow experiment of 2000.

27. Graphs showing lateral water-temperature patterns and differences from mainstem temperature for the open-channel site RK 416.2L along the Colorado River in Grand Canyon during the Low Steady Summer Flow experiment of 2000.

28. Aerial thermal-infrared image of water-surface temperature of shoreline-cavity site RK104.6L on July 25,2000 . 


\section{Tables}

1. Sensor type, temperature range, accuracy, and survival range of the Campbell Scientific 107B-L temperature probe, according to manufacturer's specifications.

2. Individual temperature sensor locations for different lengths of thermistor-strings used to determine nearshore temperatures in the Colorado River in Grand Canyon during the Low Steady Summer Flow experiment of 2000

3. Study-site location, environment type, thermistor-string length, deployment dates, and deployment duration for determination of nearshore temperatures in the Colorado River in Grand Canyon during the Low Steady Summer Flow experiment of 2000.

4. Study-site type and location, daytime and nighttime minimum and maximum temperature differences from the mainstem, and the distance from the shoreline where the minimum and maximum temperature differences were recorded for determination of nearshore temperatures in the Colorado River in Grand Canyon during the Low Steady Summer Flow experiment of 2000.

\section{Conversion Factors}

SI to Inch/Pound

\begin{tabular}{lcl}
\hline \multicolumn{1}{c}{ Multiply } & \multicolumn{1}{c}{ By } & \multicolumn{1}{c}{ To obtain } \\
\hline centimeter $(\mathrm{cm})$ & 0.3937 & inch \\
meter $(\mathrm{m})$ & 3.281 & foot $(\mathrm{ft})$ \\
kilometer $(\mathrm{km})$ & 0.6214 & mile $(\mathrm{mi})$ \\
meter $(\mathrm{m})$ & 1.094 & yard $(\mathrm{yd})$ \\
\hline & Volume & \\
\hline cubic meter $\left(\mathrm{m}^{3}\right)$ & 264.2 & gallon $(\mathrm{gal})$ \\
cubic meter $\left(\mathrm{m}^{3}\right)$ & 1.308 & cubic yard $\left(\mathrm{yd}{ }^{3}\right)$ \\
cubic meter $\left(\mathrm{m}^{3}\right)$ & 0.0008107 & acre-foot $(\mathrm{acre}-\mathrm{ft})$ \\
\hline & Flow rate & \\
\hline cubic meter per second $\left(\mathrm{m}^{3} / \mathrm{s}\right)$ & 70.07 & acre-foot per day $(\mathrm{acre}-\mathrm{ft} / \mathrm{d})$ \\
meter per second $(\mathrm{m} / \mathrm{s})$ & 3.281 & foot per second $(\mathrm{ft} / \mathrm{s})$ \\
cubic meter per second $\left(\mathrm{m}^{3} / \mathrm{s}\right)$ & 35.31 & cubic foot per second $(\mathrm{ft} / \mathrm{s})$ \\
cubic meter per second $\left(\mathrm{m}^{3} / \mathrm{s}\right)$ & 22.83 & million gallons per day $(\mathrm{Mgal} / \mathrm{d})$ \\
\hline
\end{tabular}

Temperature in degrees Celsius $\left({ }^{\circ} \mathrm{C}\right)$ may be converted to degrees Fahrenheit $\left({ }^{\circ} \mathrm{F}\right)$ as follows:

${ }^{\circ} \mathrm{F}=\left(1.8 x^{\circ} \mathrm{C}\right)+32$ 


\title{
Water Temperatures in Select Nearshore Environments of the Colorado River in Grand Canyon, Arizona, During the Low Steady Summer Flow Experiment of 2000
}

\author{
By William S. Vernieu ${ }^{1}$ and Craig R. Anderson ${ }^{2}$
}

\begin{abstract}
Water releases from Glen Canyon Dam, Arizona, are the primary determinant of streamflow, sediment transport, water quality, and aquatic and riparian habitat availability in the Colorado River downstream of the dam in Grand Canyon. The presence and operation of the dam have transformed the seasonally warm Colorado River into a consistently cold river because of hypolimnetic, or deep-water, releases from the penstock withdrawal structures on the dam. These releases have substantially altered the thermal regime of the downstream riverine environment. This, in turn, has affected the biota of the river corridor, particularly native and nonnative fish communities and the aquatic food web.

In the spring and summer of 2000, a Low Steady Summer Flow experiment was conducted by the U.S. Geological Survey and the Bureau of Reclamation to evaluate the effects of the experimental flow on physical and biological resources of the Colorado River ecosystem downstream from Glen Canyon Dam to Lake Mead on the Arizona-Nevada border. This report describes the water temperatures collected during the experimental flow from 14 nearshore sites in the river corridor in Grand Canyon to assess the effects of steady releases on the thermal dynamics of nearshore environments. These nearshore areas are characterized by low-velocity flows with some degree of isolation from the higher velocity flows in the main channel and are hypothesized to be important rearing environments for young native fish.

Water-temperature measurements were made at 14 sites, ranging from backwater to openchannel environments. Warming during daylight hours, relative to main-channel temperatures, was measured at all sites in relation to the amount of isolation from the main-channel current. Boat traffic, amount of direct solar radiation, and degree of isolation from the main-channel current appear to be the primary factors affecting the differential warming of the nearshore environment.
\end{abstract}

\section{Introduction}

The presence and operation of Glen Canyon Dam have transformed the seasonally warm Colorado River into a consistently cold river because of hypolimnetic, or deep-water, releases from the penstock withdrawal structures on the dam. These releases have substantially altered the thermal regime of the downstream riverine environment. This, in turn, has affected the biota of the river corridor, particularly native and nonnative fish communities and the aquatic food web.

\footnotetext{
${ }^{1}$ U.S. Geological Survey, Grand Canyon Monitoring and Research Center, Flagstaff, Ariz.

${ }^{2}$ U.S. Fish and Wildlife Service, Bay-Delta Fish and Wildlife Office, Sacramento, Calif.
} 
In the spring and summer of 2000, a Low Steady Summer Flow experiment was conducted by the U.S. Geological Survey (USGS) and the Bureau of Reclamation to evaluate the effects of the experimental flow on physical and biological resources of the Colorado River ecosystem downstream from Glen Canyon Dam to Lake Mead on the Arizona-Nevada border. In this study, water-temperature measurements were made in a variety of nearshore habitat types to determine the amount of warming above mainchannel temperatures that can result under steady-flow conditions.

Throughout this report, discharges are given in both cubic meters per second $\left(\mathrm{m}^{3} / \mathrm{s}\right)$ and cubic feet per second $\left(\mathrm{ft}^{3} / \mathrm{s}\right)$ because of local familiarity with latter unit of discharge.

\section{Grand Canyon Thermal Dynamics}

The installation of Glen Canyon Dam (GCD) in 1963 and its subsequent operation altered the hydrological, physical, and biological functions and characteristics of the Colorado River ecosystem and affected streamflow, sediment transport, water temperature, and aquatic and riparian habitats downstream from the dam in Grand Canyon (Converse and others, 1998; Schmidt and others, 2007). Dam operations have transformed the Colorado River from a river with a seasonally variable hydrograph to a river with substantial daily variability but much less seasonal variability (Topping and others, 2003). Sediment entrapment in the upstream reservoir behind the dam (Lake Powell) has reduced sediment inputs, and changes in flow patterns have caused a redistribution of downstream sandbars and other fine-grained deposits (Topping and others, 2000; Rubin and others, 2002; Wright and others, 2005). The presence and operation of the dam have also altered the thermal dynamics of the downstream riverine environment.

Before flow regulation caused by the operation of the dam, the average annual water temperature at Lees Ferry, approximately 25 kilometers $(\mathrm{km})$ downstream from GCD, was 14.0 degrees Celsius $\left({ }^{\circ} \mathrm{C}\right)$ and fluctuated from near freezing in the winter to nearly $30^{\circ} \mathrm{C}$ in the summer (Voichick and Wright, 2007). From 1973 to 2003, after regulation, the average annual GCD release temperature, measured at Lees Ferry, was $9.3^{\circ} \mathrm{C}$, with seasonal fluctuations between $7^{\circ} \mathrm{C}$ in the spring and $12^{\circ} \mathrm{C}$ in late autumn and early winter (Vernieu and others, 2005). These water-temperature changes have altered the linkages between the terrestrial ecosystem, the aquatic food web, and the native and nonnative fish communities in the Grand Canyon (Blinn and others, 1995; Gloss and Coggins, 2005; Kennedy and Gloss, 2005; Ralston, 2005). Of particular interest are the effects of these changes on native fish species, including the endangered humpback chub (Gila cypha). Release temperatures from GCD are too cold to support mainstem spawning and are hypothesized to limit larval survival and decrease the likelihood of recruitment of young native fish into the adult population (Kaeding and Zimmerman, 1983; Valdez and Ryel, 1995; Converse and others, 1998; Gorman and Stone, 1999). It has been shown that juvenile humpback chub preferentially select nearshore habitats that are typically shallow, low-velocity environments with the potential for enhanced warming, as compared to the water temperature in the mainstem (Converse and others, 1998; Korman and others, 2004; Stone and Gorman, 2006).

Thermal dynamics of streams and rivers are primarily controlled by surface heat exchange and transport mechanisms (Thomann and Mueller, 1987). In dam-regulated rivers, like the Colorado River in Grand Canyon, water-release volumes and daily release patterns play an important role in determining the river's thermal characteristics and the resulting habitat that is available to aquatic biota. The incised river corridor downstream of GCD results in a highly heterogeneous radiative regime, with differential shading from the steep canyon walls. It is hypothesized that reduction of daily flow fluctuations has the potential to reduce mixing of nearshore environments with the mainstem, thus increasing the potential for warming in these nearshore areas. Previous field studies have documented 
enhanced warming in nearshore environments on the Colorado River (Parnell and others, 1997; Korman and others, 2006; Kaplinski, 2006; Ralston and others, 2007). Remotely sensed data collected with forward-looking infrared (FLIR) instrumentation have demonstrated warming in nearshore environments in both the Little Colorado and Colorado Rivers in the Grand Canyon (Holroyd, 1995a,b; Eckhardt, 1998; Davis, 2002). Despite the relative abundance of literature describing temperature in the Colorado River downstream from GCD and the well-known physical processes governing heat exchange and hydrodynamic transport, a comprehensive understanding of thermal dynamics in nearshore environments has yet to be developed.

\section{Study Area}

The study area included approximately $476.2 \mathrm{~km}$ of the Colorado River from GCD to Lake Mead in northeast Arizona (fig. 1). The Colorado River in this area is regulated by GCD and flows through an incised river corridor up to 2,048 meters (m) deep in Grand Canyon in northwest Arizona. Site locations are identified by river-channel distances from Lees Ferry and expressed in river kilometers (RK; U.S. Geological Survey, 2011). By convention, Lees Ferry is located at RK 0.0 with negative values upstream to GCD at RK -25.6 and positive values downstream. Diamond Creek is located at RK 363.7.

\section{The Low Steady Summer Flow Experiment}

A Low Steady Summer Flow (LSSF) experiment was conducted during the spring and summer of 2000 as a requirement of the U.S. Fish and Wildlife Service Biological Opinion (U.S. Fish and Wildlife Service, 1994) in response to the Final Environmental Impact Statement Record of Decision on the Operation of Glen Canyon Dam (U.S. Department of the Interior, 1996). This experiment was part of an ongoing program conducted by the U.S. Geological Survey to evaluate the effects of prescribed dam releases on various components of the Colorado River ecosystem (CRE) downstream from GCD, particularly native and endangered fishes of the Colorado River in Grand Canyon. It is believed that low, steady releases during summer would provide thermal conditions that would benefit the endangered humpback chub and other native fish species and thus assist in complying with the Endangered Species Act. This experiment consisted of more than just steady flows during summer; it consisted of several distinct flow regimes, including high steady discharge, 4-day spike flows at powerplant capacity in the spring and again in the fall, and low steady discharge during summer. A steady discharge of approximately $226 \mathrm{~m}^{3} / \mathrm{s}\left(8,000 \mathrm{ft}^{3} / \mathrm{s}\right)$ was released from GCD from June 1 to October 1, 2000, except for 5 days in September (September 5-8 and 18, 2000; fig. 2).

\section{Purpose and Scope}

The purpose of this report is to describe the nearshore water temperatures in the Colorado River from GCD to Lake Mead during the LSSF experiment in summer 2000. Data collected at a frequency of 5 minutes are presented from 14 locations representing 5 types of nearshore environments. 


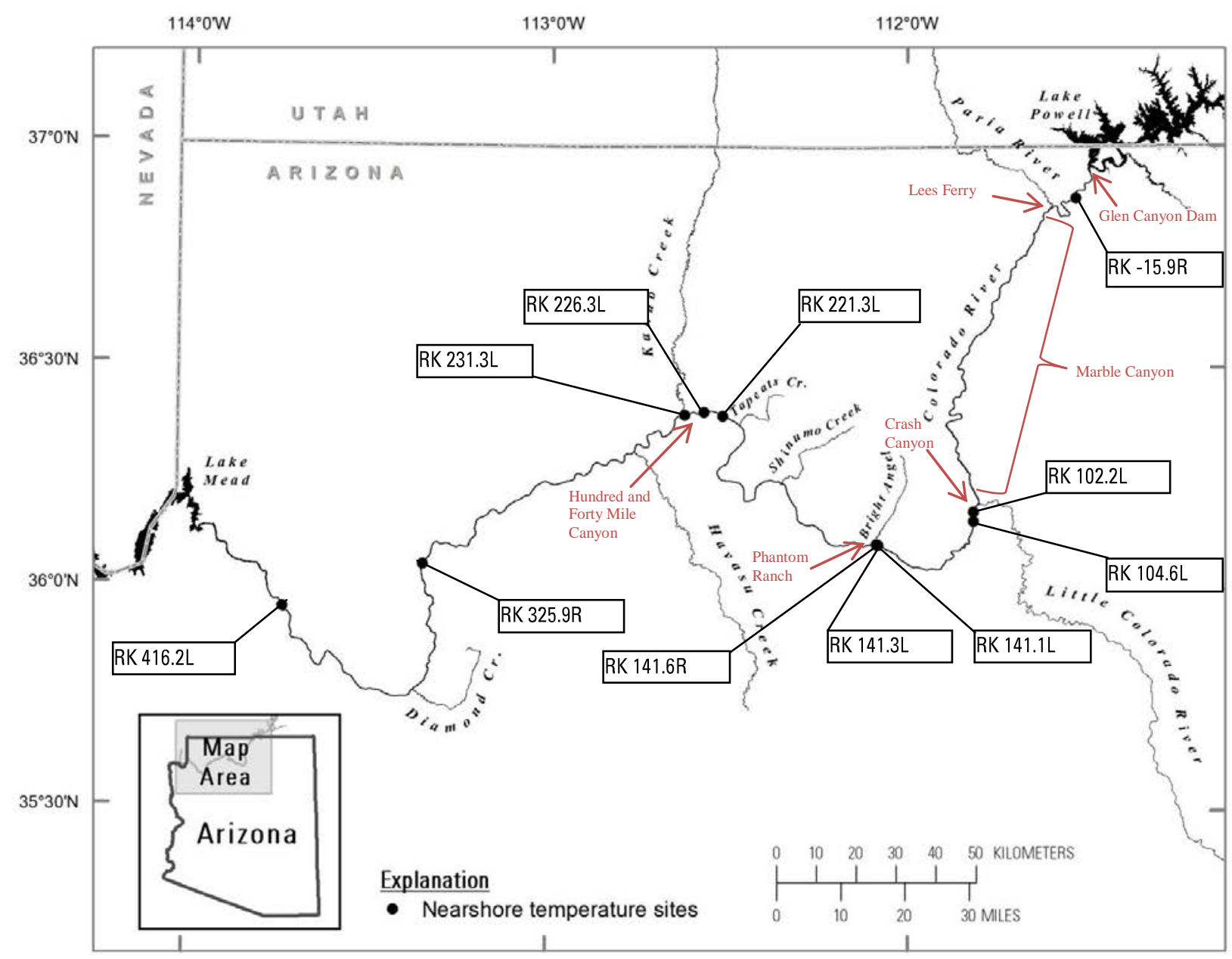

Figure 1. Map of the Colorado River and its tributaries between Lake Powell and Lake Mead, northern Arizona, showing nearshore water-temperature study sites described in this report. RK, river-channel distances from Lees Ferry expressed in river kilometers; $R$ (right) and $L$ (left), side of the river looking downstream. 


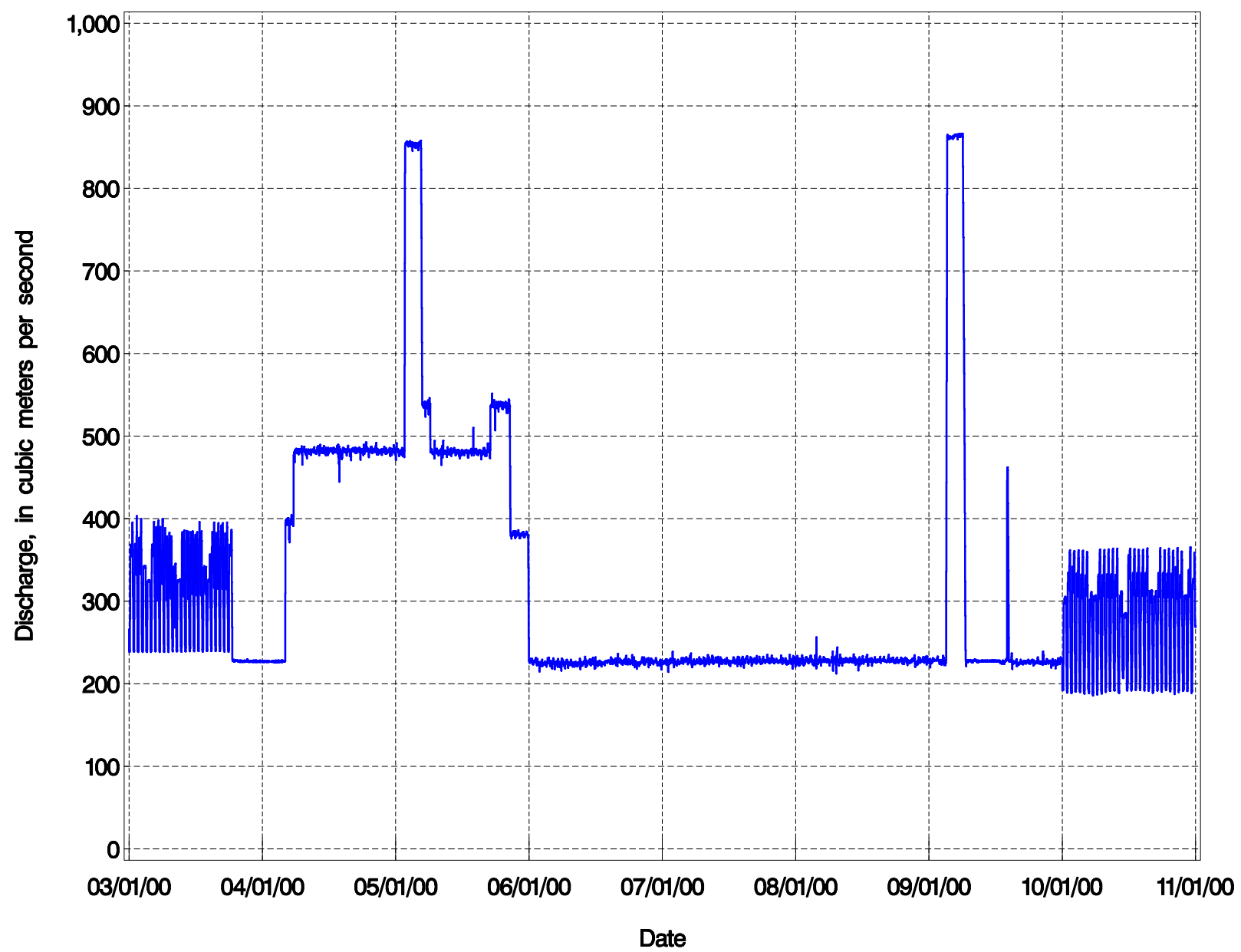

Figure 2. Graph showing hourly Glen Canyon Dam discharge from March 1 through October 31, 2000, including the Low Steady Summer Flow experiment from March 25 through September 30, 2000.

\section{Methods}

\section{Dam-Release and Sampling Schedule}

The LSSF experiment was conducted from March 25 through September 30, 2000, and consisted of several distinct flow regimes (fig. 2). Releases from GCD consisted of:

- 12-day flows of approximately $226 \mathrm{~m}^{3} / \mathrm{s}\left(8,000 \mathrm{ft}^{3} / \mathrm{s}\right)$ from March 25 to April 6, 2000

- 26-day high, steady flows of approximately $481 \mathrm{~m}^{3} / \mathrm{s}\left(17,000 \mathrm{ft}^{3} / \mathrm{s}\right)$ from April 6 to May 3, 2000

- 4-day spike flow of approximately $850 \mathrm{~m}^{3} / \mathrm{s}\left(30,000 \mathrm{ft}^{3} / \mathrm{s}\right)$ from May 3 to 7,2000

- 21-day steady flows of $481 \mathrm{~m}^{3} / \mathrm{s}\left(17,000 \mathrm{ft}^{3} / \mathrm{s}\right), 538 \mathrm{~m}^{3} / \mathrm{s}\left(19,000 \mathrm{ft}^{3} / \mathrm{s}\right)$, and $368 \mathrm{~m}^{3} / \mathrm{s}\left(13,000 \mathrm{ft}^{3} / \mathrm{s}\right)$ from May 7 to June 1, 2000

- 96-day low, steady flows of approximately $226 \mathrm{~m}^{3} / \mathrm{s}\left(8,000 \mathrm{ft}^{3} / \mathrm{s}\right)$ from June 1 to September 5,2000

- 4-day spike flow of approximately $850 \mathrm{~m}^{3} / \mathrm{s}\left(30,000 \mathrm{ft}^{3} / \mathrm{s}\right)$ from September 5 to 9,2000

- 22-day low, steady releases of approximately $226 \mathrm{~m}^{3} / \mathrm{s}\left(8,000 \mathrm{ft}^{3} / \mathrm{s}\right)$ from September 9 to October 1 , with a 10-hr excursion to $461 \mathrm{~m}^{3} / \mathrm{s}\left(16,300 \mathrm{ft}^{3} / \mathrm{s}\right)$ on September 18, 2000 
Three water-temperature sampling trips were conducted during the LSSF to coincide with native fish sampling efforts, July 24-August 3, August 16-18, and August 21, 2000. All measurements during this study were made during steady flows of $226 \mathrm{~m}^{3} / \mathrm{s}$.

\section{Instrumentation and Thermistor-String Design}

Nearshore water-surface temperatures were measured using four horizontally deployed thermistor strings of varying lengths $(5,10,15$, and $25 \mathrm{~m})$ in a variety of habitat types (fig. 3). The length of each thermistor string chosen for deployment was dependent on the physical characteristics of each site. Each thermistor string consisted of five Campbell Scientific 107B-L temperature sensors connected to Campbell Scientific CR10 dataloggers powered by sealed lead-acid batteries. Table 1 presents a summary of the manufacturer's specifications for the temperature sensors. The temperature sensors were attached to a 3/32-inch stainless steel strain-relief cable at specified distance intervals from the shoreline (table 2 and fig. 3). The horizontal distance intervals between temperature sensors varied for each thermistor string, with smaller intervals closer to shore. Temperature sensors were inserted in blocks of closed-cell foam that shaded the sensors from sunlight and allowed the sensors to extend no more than 10 centimeters $(\mathrm{cm})$ below the water surface. Thermistor strings were extended perpendicular to the shoreline and anchored underwater using concrete weights (fig. 3). Additional blocks of closedcell foam at intermediate points between the temperature sensors and a larger float near the river anchor supported the thermistor string horizontally at the water surface. Additional temperature sensors were deployed onshore to measure corresponding air temperatures and, where applicable, on the anchor to approximate mainstem river temperatures at depth (fig. 3). Voichick and Wright (2007), using the methodology described by Wagner and others (2006), found that nearshore deployments in regions of moderate to strong current at three long-term water-quality monitoring sites in the Grand Canyon adequately characterized the average water temperature across the channel. 
Table 1. Sensor type, temperature range, accuracy, and survival range of the Campbell Scientific 107B-L temperature probe, according to manufacturer's specifications (http://www.campbellsci.com/107-I, accessed July, 1, 2011).

$\left[ \pm\right.$, plus or minus; ${ }^{\circ} \mathrm{C}$, degree Celsius]

\begin{tabular}{lc}
\hline & Campbell Scientific 107B-L temperature probe \\
\hline Sensor & BetaTherm 100K6A Thermistor \\
Temperature Measurement Range & -35 to $50^{\circ} \mathrm{C}$ \\
Accuracy & Typically less than $\pm 0.2^{\circ} \mathrm{C}$ over 0 to $50^{\circ} \mathrm{C}$ range \\
Survival Range & -50 to $100^{\circ} \mathrm{C}$ \\
\hline
\end{tabular}

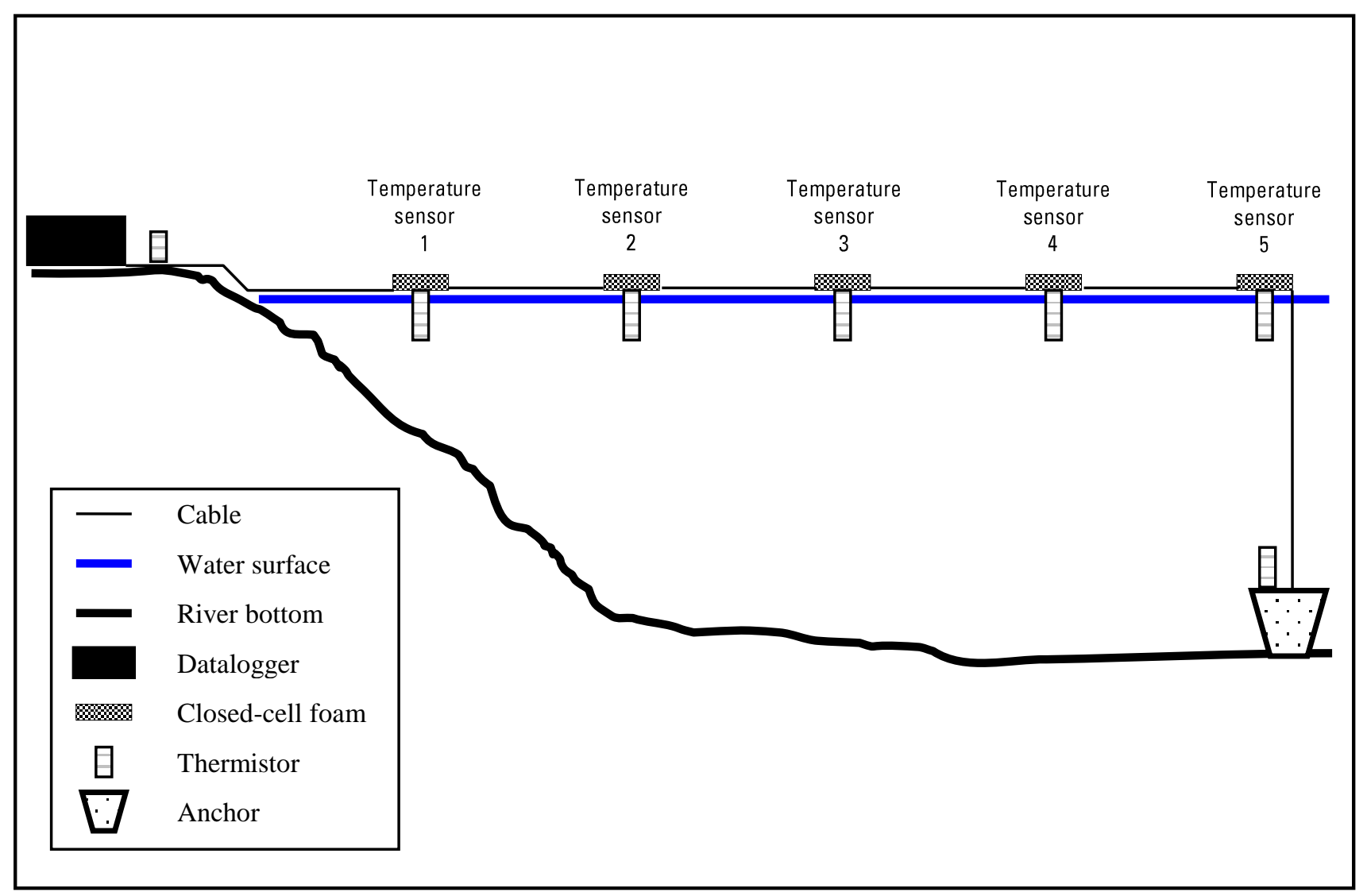

Figure 3. Schematic diagram of thermistor-string deployment for determination of nearshore temperatures in the Colorado River in Grand Canyon during the Low Steady Summer Flow experiment of 2000. 
Table 2. Individual temperature sensor locations for different lengths of thermistor-strings used to determine nearshore temperatures in the Colorado River in Grand Canyon during the Low Steady Summer Flow experiment of 2000 (see fig. 3).

$[\mathrm{m}$, meter]

\begin{tabular}{cccccc}
\hline $\begin{array}{c}\text { Thermistor-string } \\
\text { length }(\mathrm{m})\end{array}$ & $\begin{array}{c}\text { Distance from } \\
\text { shore, } \\
\text { temperature } \\
\text { sensor } \mathbf{1}(\mathrm{m})\end{array}$ & $\begin{array}{c}\text { Distance from } \\
\text { shore, } \\
\text { temperature } \\
\text { sensor } \mathbf{2}(\mathrm{m})\end{array}$ & $\begin{array}{c}\text { Distance from } \\
\text { shore, } \\
\text { temperature } \\
\text { sensor } \mathbf{3}(\mathrm{m})\end{array}$ & $\begin{array}{c}\text { Distance from } \\
\text { shore, } \\
\text { temperature } \\
\text { sensor } \mathbf{4}(\mathrm{m})\end{array}$ & $\begin{array}{c}\text { Distance from } \\
\text { shore, } \\
\text { temperature } \\
\text { sensor } \mathbf{5}(\mathrm{m})\end{array}$ \\
\hline 5.0 & 0.5 & 1.0 & 2.0 & 3.0 & 5.0 \\
10.0 & 1.0 & 2.0 & 3.0 & 5.0 & 10.0 \\
15.0 & 1.0 & 3.0 & 5.0 & 10.0 & 15.0 \\
25.0 & 2.0 & 5.0 & 15.0 & 25.0 & 27.0 \\
\hline
\end{tabular}

\section{Deployments and Site Descriptions}

Thermistor strings were deployed at 14 locations in five types of environments: backwaters, shoreline cavities, cobble bars, eddies, and open channels (table 3). These thermistor-string deployments represent temperature conditions at sites selected in coordination with the logistical constraints of three separate fishery surveys. Therefore, temperature measurements were not made in every type of environment. Sites were selected based on the length of stay in a given area and the potential of a given site to exhibit measurable warming. At one cobble-bar site, additional deployments were made for replication and to measure warming along a longitudinal gradient parallel to river flow.

Flow characteristics for the selected environments ranged from quiescent in backwaters (highest degree of mainstem isolation) and shoreline cavities to low velocities in some nearshore, open-channel environments (lowest degree of mainstem isolation). Thermistor-string lengths were selected based on the physical configuration of each site. Deployments ranged from 19 to 50 hours dependent on logistical considerations. Site IDs used in this study are in river kilometers from Lees Ferry followed by an "R" or an " $L$ " to denote the right or left side or the river, respectively, looking downstream. 
Table 3. Study-site location, environment type, thermistor-string length, deployment dates, and deployment duration for determination of nearshore temperatures in the Colorado River in Grand Canyon during the Low Steady Summer Flow experiment of 2000.

[RK, river kilometers from Lees Ferry; R (right) and L (left), side of the river looking downstream; m, meter; mm/dd/yyyy hhmm, month/day/year hour and minute; hrs, hours; N/A, not available]

\begin{tabular}{|c|c|c|c|c|c|c|c|}
\hline Nearshore environment & $\begin{array}{c}\text { Site } \\
\text { location } \\
\text { (RK) }\end{array}$ & $\begin{array}{l}\text { Thermistor } \\
\text { string length } \\
\text { (m) }\end{array}$ & $\begin{array}{c}\text { Start date } \\
\text { (mm/dd/yyyy hh:mm) }\end{array}$ & $\begin{array}{c}\text { End date } \\
\text { (mm/dd/yyyy hh:mm) }\end{array}$ & $\begin{array}{l}\text { Deployment } \\
\text { duration } \\
\text { (hrs) }\end{array}$ & $\begin{array}{l}\text { Image } \\
\text { figures }\end{array}$ & $\begin{array}{r}\text { Graph } \\
\text { figures }\end{array}$ \\
\hline Backwater & $141.6 \mathrm{R}$ & 25 & 07/26/2000 14:45 & 07/28/2000 16:50 & 50.4 & 4 & 14 \\
\hline Shoreline Cavity & $104.6 \mathrm{~L}$ & 10 & 07/24/2000 11:20 & 07/25/2000 14:05 & 27.1 & 5 & 15 \\
\hline Cobble Bar-upper & $325.9 \mathrm{R}$ & 5 & 08/02/2000 12:00 & 08/03/2000 09:15 & 21.3 & 6 & 16 \\
\hline Cobble Bar-lower & $325.9 \mathrm{R}$ & 10 & 08/02/2000 12:25 & 08/03/2000 09:25 & 21.0 & 6 & 17 \\
\hline Cobble Bar-longitudinal & $325.9 \mathrm{R}$ & 25 & 08/02/2000 13:05 & 08/03/2000 09:50 & 21.0 & 6 & 18 \\
\hline Eddy & $102.2 \mathrm{~L}$ & 25 & 07/24/2000 10:30 & 07/25/2000 13:45 & 27.4 & 7 & 19 \\
\hline Eddy & $141.1 \mathrm{~L}$ & 5 & 07/26/2000 11:20 & 07/28/2000 09:15 & 46.0 & 8 & 20 \\
\hline Eddy & $141.3 \mathrm{~L}$ & 10 & 07/27/2000 09:55 & 07/28/2000 18:05 & 32.2 & 9 & 21 \\
\hline Eddy-upper & $221.3 \mathrm{~L}$ & 5 & 07/30/2000 16:10 & 07/31/2000 11:05 & 18.9 & N/A & 22 \\
\hline Eddy-lower & $221.3 \mathrm{~L}$ & 10 & 07/30/2000 16:00 & 07/31/2000 10:50 & 18.9 & N/A & 23 \\
\hline Eddy & $226.3 \mathrm{~L}$ & 10 & 08/17/2000 11:00 & 08/18/2000 18:15 & 31.3 & 10 & 24 \\
\hline Eddy & $231.3 \mathrm{~L}$ & 5 & 08/17/2000 09:00 & 08/18/2000 18:00 & 33.0 & 11 & 25 \\
\hline Open Channel & $-15.9 \mathrm{R}$ & 15 & 08/16/2000 13:05 & 08/17/2000 15:40 & 27.5 & 12 & 26 \\
\hline Open Channel & $416.2 \mathrm{~L}$ & 15 & 08/21/2000 17:55 & 08/22/2000 12:45 & 19.0 & 13 & 27 \\
\hline
\end{tabular}




\section{Backwaters}

A backwater environment is defined here as an area of ponded water shoreward from an emergent sandbar that exhibits extreme low-velocity flow, surrounded by land on at least three sides, and open to exchange of flow with the main current at one end of the embayment (McGuinn-Robbins, 1995; Schmidt and others, 2007). Persistent backwaters primarily form in return-current channels associated with reattachment bars. A reattachment bar is a structure formed by sediment deposition near the point where stream flow reattaches to the bank downstream from a recirculating zone caused by a channel expansion (Rubin and others, 1990; Schmidt and Graf, 1990). A backwater develops when the reattachment bar is exposed and the associated return-current channel is partially inundated. During this study, one backwater environment was sampled at RK 141.6.

\section{RK 141.6R}

The backwater at RK 141.6R was a long (approximately $27 \mathrm{~m}$ ) return-current channel located just upstream of the Phantom Ranch boat beach and parallel to the river channel (fig. 4). The backwater was approximately $15 \mathrm{~m}$ wide at the mouth (upstream end) and tapered to a width of less than $1 \mathrm{~m}$ at the toe (terminal end). Water depths ranged from $0.8 \mathrm{~m}$ at the mouth to $0.1 \mathrm{~m}$ at the toe. Substantial aquatic vegetation was present in the last $2 \mathrm{~m}$ of the terminal end of the backwater, limiting mixing in this area. This site was the most isolated from the mainstem current compared to all of the other study sites. A 25$\mathrm{m}$ thermistor string was deployed for 50.4 hours at this site from July 26 to 28, 2000.

\section{Shoreline Cavities}

A shoreline cavity is defined as an involution of the shoreline where flow velocities are relatively low or stagnant. Shoreline cavities maintain a relatively high degree of separation from the mainstem current. Examples of shoreline cavities include ponded areas below debris fans and other channel constrictions, low-velocity areas formed by complex shoreline structures and bank irregularities (boulders, partially submerged terrestrial vegetation, bedrock protrusions, and mud flats), and embayments located in scalloped shoreline areas that allow some separation from the mainstem current. Although backwater environments exhibit similar physical characteristics, shoreline cavities are distinct geomorphic features that require a separate classification. During this study, one shoreline cavity environment was sampled at RK 104.6L.

\section{RK 104.6L}

The shoreline cavity at RK 104.6L was a low-velocity pocket below a small debris fan where the mainstem current was diverted to the right side of the river (fig. 5). The shoreline cavity was approximately $12 \mathrm{~m}$ wide at the mainstem channel margin and approximately $4 \mathrm{~m}$ wide at the shoreline boundary. Water depths ranged from $1.4 \mathrm{~m}$ at the mainstem channel margin to $0.2 \mathrm{~m}$ at the shoreline boundary. Flow conditions at this site transitioned from quiescent at the shoreline to low-velocity, recirculating flow nearer to the main channel. Low-magnitude surge waves generated by wind or intermittent boat travel near the site repeatedly flushed the study site with cooler water. A $10-\mathrm{m}$ thermistor string was deployed for 27.1 hours at this site from July 24 to 25, 2000. 

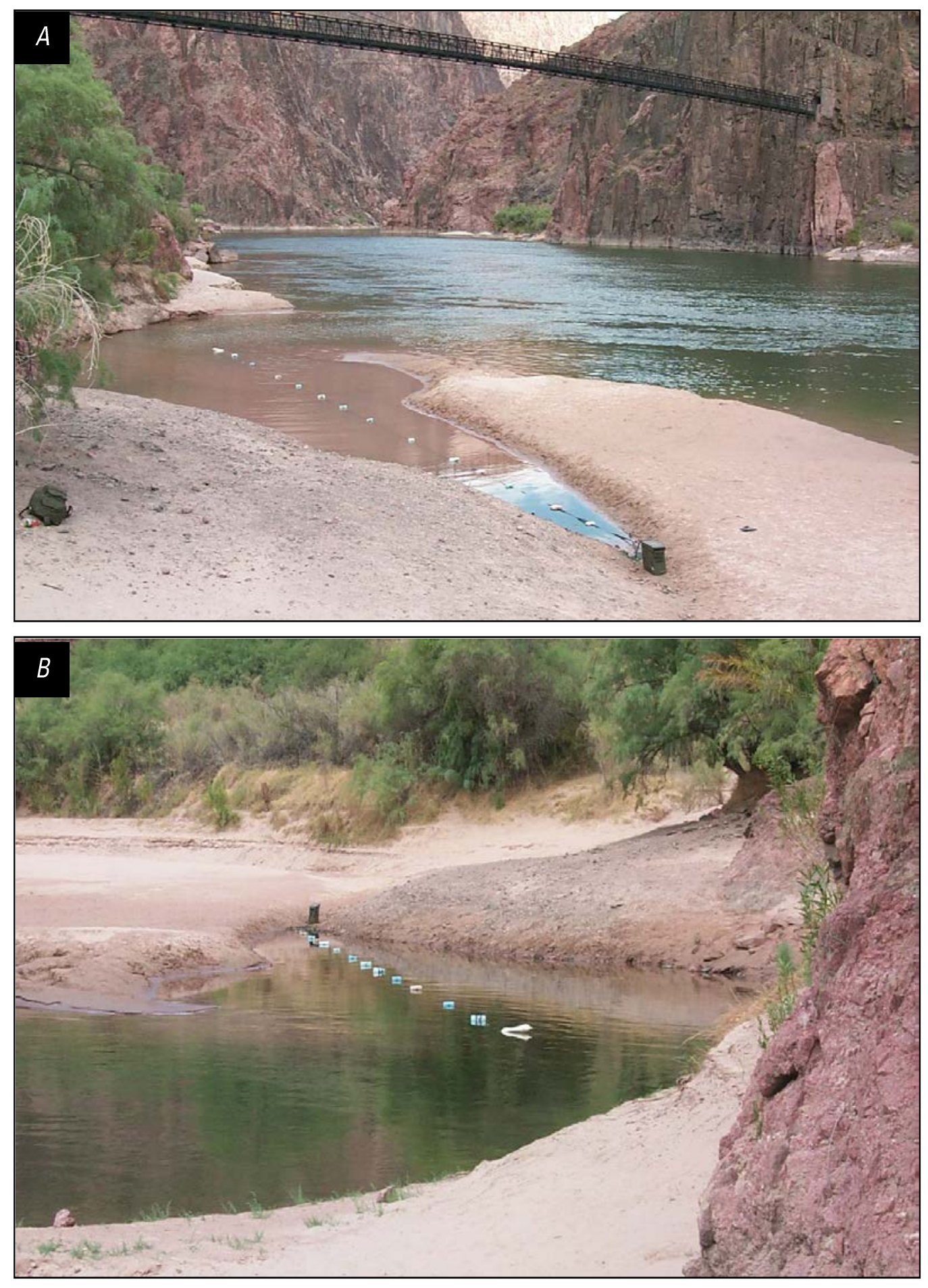

Figure 4. Photographs of the backwater site RK $141.6 \mathrm{R}$ and the 25-meter thermistor-string deployment for determination of nearshore temperatures in the Colorado River in Grand Canyon during the Low Steady Summer Flow experiment of 2000 looking upstream $(A)$ and downstream $(B)$ (U.S. Geological Survey photographs by William S. Vernieu). 

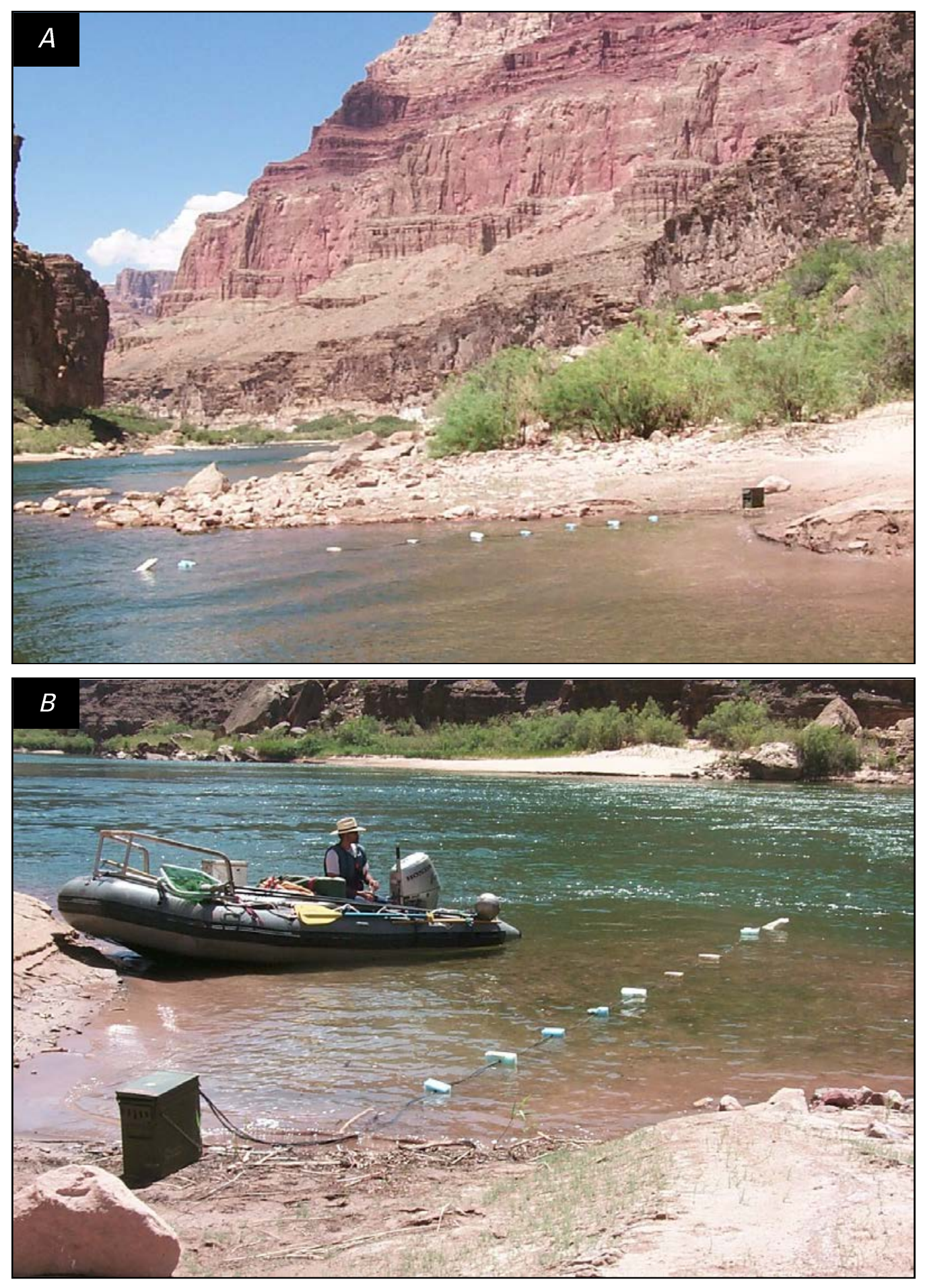

Figure 5. Photographs of the shoreline cavity site RK 104.6L and the 10-meter thermistor-string deployment for determination of nearshore temperatures in the Colorado River in Grand Canyon during the Low Steady Summer Flow experiment of 2000 looking upstream $(A)$ and across the channel $(B)$ (U.S. Geological Survey photographs by William S. Vernieu). 


\section{Cobble Bars}

Cobble bars are comprised of well-rounded and well-sorted cobbles as much as $50 \mathrm{~cm}$ in diameter. These features are present throughout Grand Canyon and generally occur upstream of constrictions, such as bedrock protrusions or tributary fans (Howard and Dolan, 1981). They also occur as a mantle on the inside bends of broadly curved rapids and as isolated bars below short, steep rapids (Dolan and others, 1978). During low flows, cobble bars have the potential to create low-velocity environments upstream and downstream from the bar and in the side channel created by the bar (Korman and others, 2004). These nearshore environments are thought to be among the preferred habitats of juvenile humpback chub (Valdez and Ryel, 1995; Converse and others, 1998). During this study, one cobble-bar environment was sampled at RK 325.9R.

\section{RK 325.9R}

Water depths at the large cobble bar at RK 325.9R were relatively shallow at three deployment sites and ranged from $0.05 \mathrm{~m}$ on the shoreline side to $0.5 \mathrm{~m}$ toward the main channel. Three thermistor strings were deployed for 21 hours near the exposed cobble bar at this site from August 2 to 3, 2000 (fig. 6). Two strings (5 and $10 \mathrm{~m}$ ) were deployed perpendicular to the irregular shoreline in shallow, low-velocity areas (fig. 6A). In addition, a 25-m string was deployed longitudinally (parallel to the current) in a separate shallow, low-velocity pocket protected on the upstream side by cobbles extending into the side channel (fig. 6B).

\section{Eddies}

Eddy environments in the Grand Canyon are typically found in recirculation zones associated with flow separation at abrupt channel expansions (Howard and Dolan, 1981; Schmidt, 1990; Rubin and others, 1990). Where separation occurs, the primary downstream current separates from the bank to form lateral recirculation eddies along the bank (Schmidt and Graf, 1990; Topping and others, 2005). In this context, an eddy is defined as an area with rotating fluid motion with a vertical or nearly vertical axis of rotation (Schmidt and Graf, 1990). Historical aerial photographs and other recent surveys indicate that these types of eddy environments account for approximately 20 percent of the surface area of the Colorado River in Marble Canyon, RK 0-RK 98 (Schmidt and others, 2004; Hazel and others, 2006). Because currents in eddy environments typically exhibit lower velocities than the mainstem, they have the potential to warm above mainstem temperatures and may serve as sheltered, warm-water habitats for native fishes, especially along shoreline margins. During this study, six eddy environments were sampled. A physical description of each of these study sites follows.

\section{RK 102.2L}

Site RK 102.2L was located in a large eddy below a moderately sized debris fan just downstream of the large cobble island downstream from Crash Canyon (fig. 7). A 25-m thermistor string was deployed for 27.4 hours at this site from July 24 to 25, 2000. The thermistor string was deployed such that the shoreward temperature sensors were located in a region of low-velocity reverse flow transitioning to low-velocity, mixed-direction flow for the temperature sensors that were closer to the main channel. 

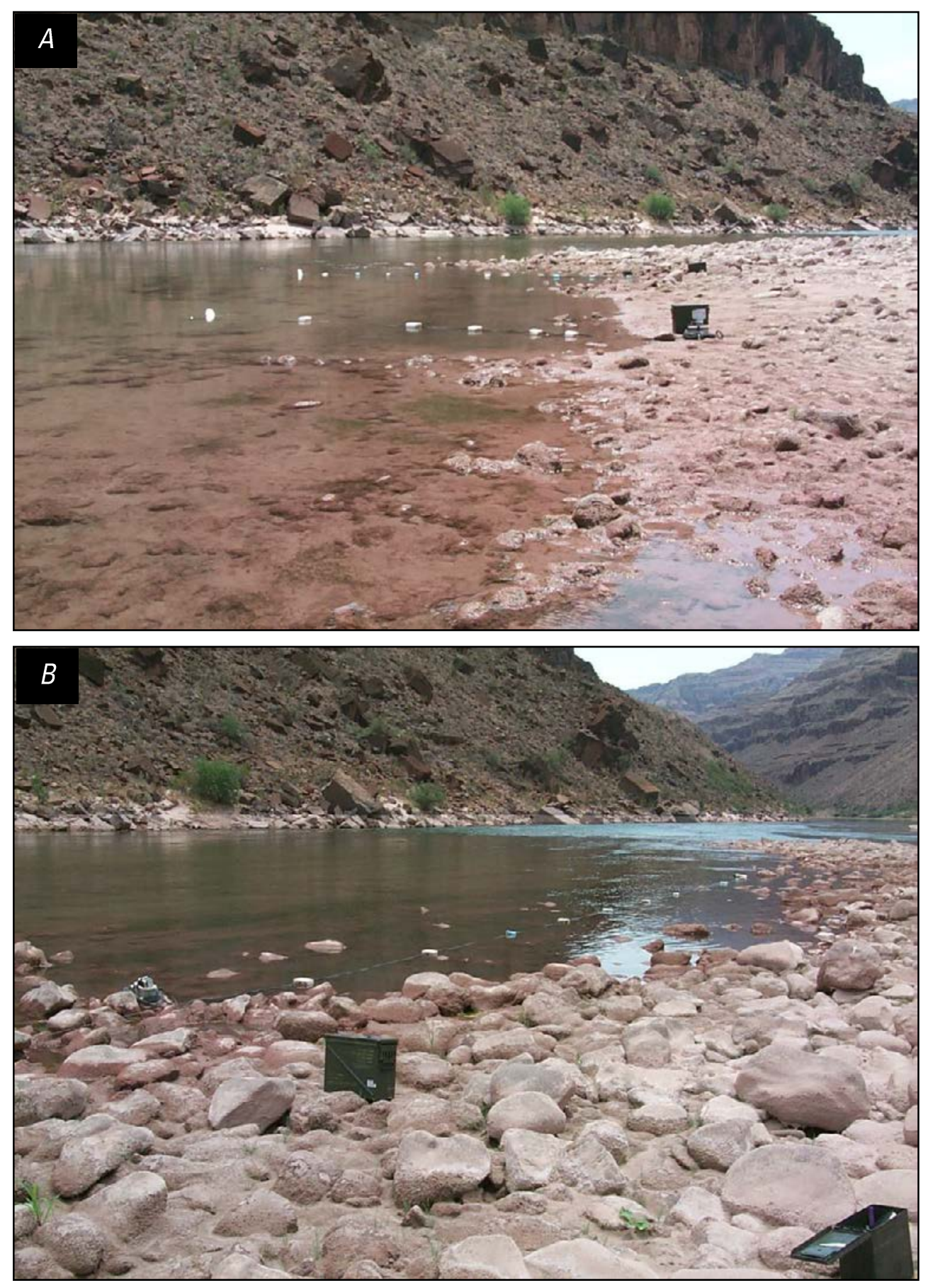

Figure 6. Photographs of the cobble-bar site RK 325.9R and the 5-meter and 10-meter thermistor-string deployments $(A)$ and the 25-meter thermistor string deployed longitudinally $(B)$ for determination of nearshore temperatures in the Colorado River in Grand Canyon during the Low Steady Summer Flow experiment of 2000 (U.S. Geological Survey photographs by William S. Vernieu). 


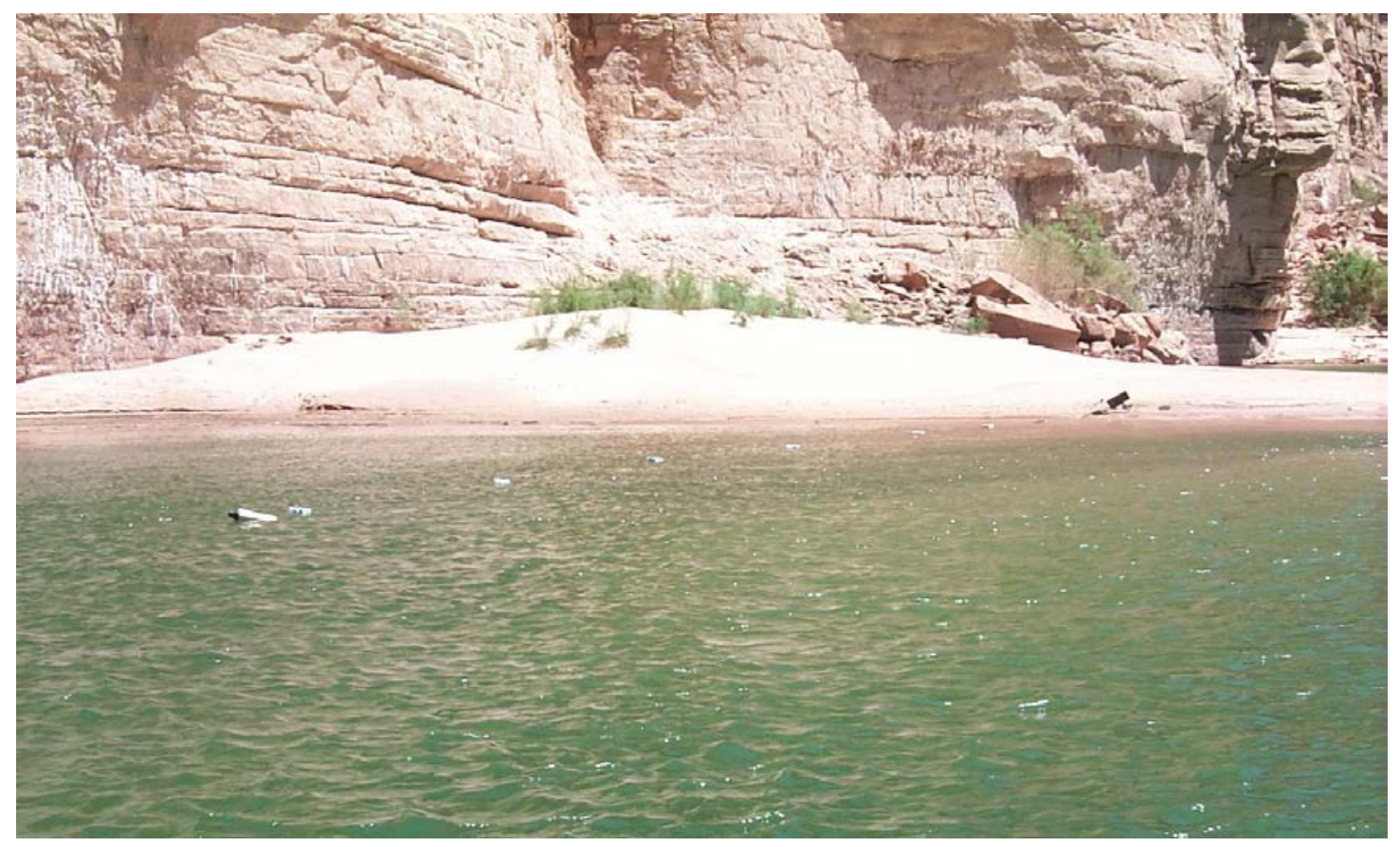

Figure 7. Photograph of the eddy site RK 102.2L and the 25-meter thermistor-string deployment for determination of nearshore temperatures in the Colorado River in Grand Canyon during the Low Steady Summer Flow experiment of 2000 looking slightly downstream from the middle of the main channel (U.S. Geological Survey photograph by William S. Vernieu).

RK 141.1L

Site RK 141.1L was located in the eddy below the debris fan that forms Cremation Camp, a short distance upstream from Phantom Ranch (fig. 8). Water depths ranged from $0.05 \mathrm{~m}$ at the shoreward sensor to $0.5 \mathrm{~m}$ at the end of the thermistor string. A 5-m thermistor string was deployed for 46 hours at this site from July 26 to 28, 2000. The thermistor string was deployed in a shallow, lowvelocity area at the convergence of two smaller eddies where a submerged sandbar platform extended from the shore.

RK 141.3L

Site RK 141.3L was located in the eddy formed by a bedrock constriction immediately downstream of the Colorado River near Grand Canyon gaging station, USGS station number 09402500 (fig. 9). A 10-m thermistor string was deployed for 32.2 hours at this site from July 27 to 28, 2000. The thermistor string was deployed at the upstream end of a point bar that formed the channel-side boundary of a return-current channel backwater. The thermistor string was deployed such that the shoreward temperature sensors were located in a region of low-velocity reverse flow transitioning to low-velocity, mixed-direction flow for the temperature sensors that approached the eddy fence. 


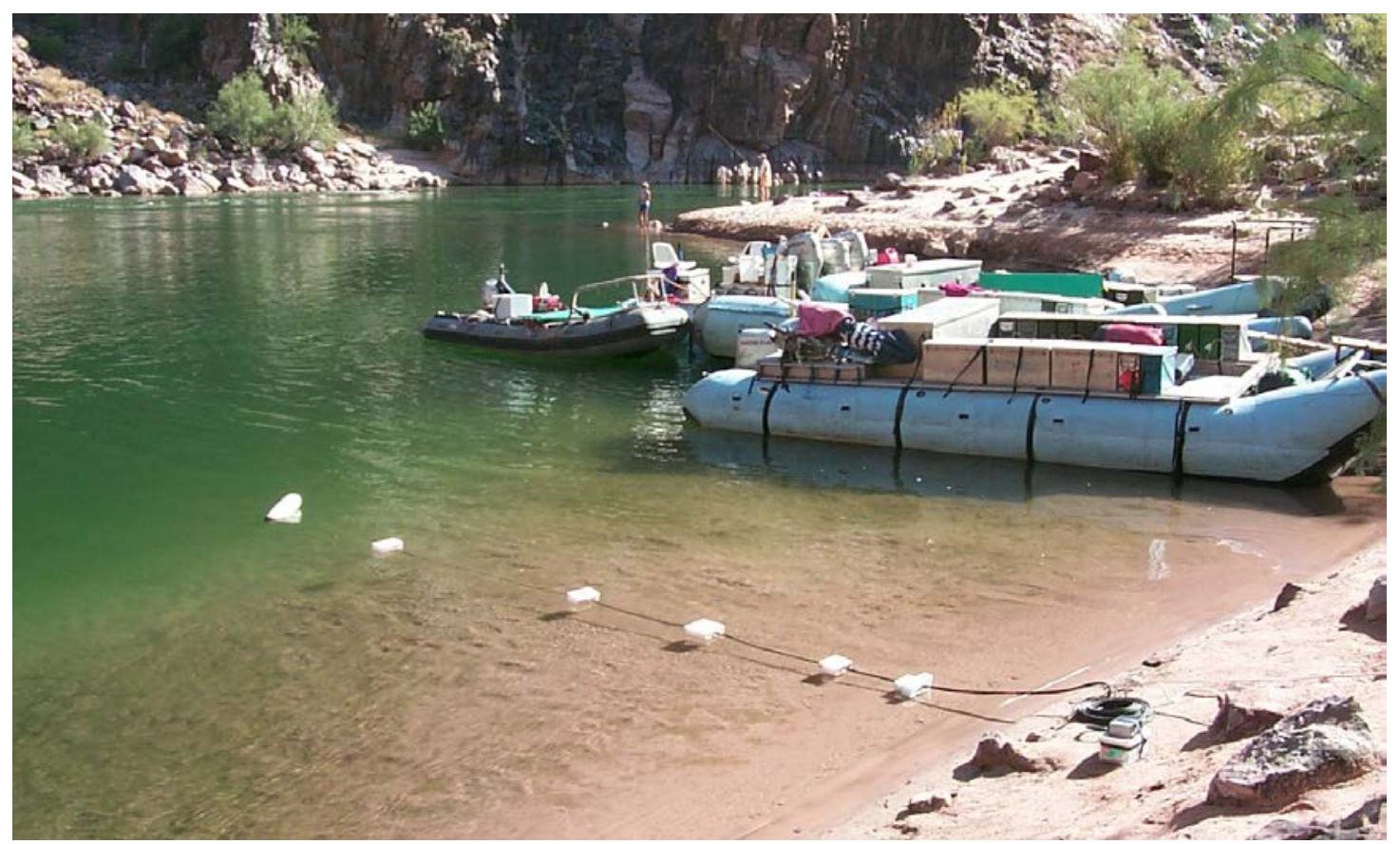

Figure 8. Photograph of the eddy site RK 141.1L and the 5-meter thermistor-string deployment for determination of nearshore temperatures in the Colorado River in Grand Canyon during the Low Steady Summer Flow experiment of 2000 looking upstream toward Cremation Camp (near Phantom Ranch) (U.S. Geological Survey photograph by William S. Vernieu).

RK 221.3L

Site RK 221.3L was located in a small eddy formed by an upstream debris-fan constriction immediately upstream of a submerged reattachment bar that was deep enough that recirculation within the eddy structure was not substantially altered. Two thermistor strings (5 and $10 \mathrm{~m})$ were deployed perpendicular to the shoreline for 19 hours from July 30 to 31, 2000, with one deployment in the lower part of the eddy and the other in the upper part of the eddy. Water depths for both deployments ranged from 0.2 to $0.85 \mathrm{~m}$.

\section{RK 226.3L}

Site RK 226.3L was located in the eddy formed by the Hundred and Forty Mile Canyon debris fan (fig. 10). A 10-m thermistor string was deployed for 31.3 hours at this site from August 17 to 18, 2000. The thermistor string was deployed in a shallow, low-velocity area of reverse flow, with increasing velocity moving away from the shoreline. Water depths ranged from $0.1 \mathrm{~m}$ at the shoreward sensor to $0.45 \mathrm{~m}$ at the end of the thermistor string.

\section{RK 231.3L}

Site RK 231.3L was located in an eddy of weak, recirculating flow formed by an irregular, rocky bank upstream (fig. 11). A 5-m thermistor string was deployed for 33 hours at this site from August 17 to 18,2000 . The thermistor string was deployed in a low-velocity area of mixed flow direction, with increasing, downstream velocity moving away from the shoreline. Water depths ranged from $0.15 \mathrm{~m}$ at the shoreward sensor to more than $2.0 \mathrm{~m}$ at the end of the thermistor string. 

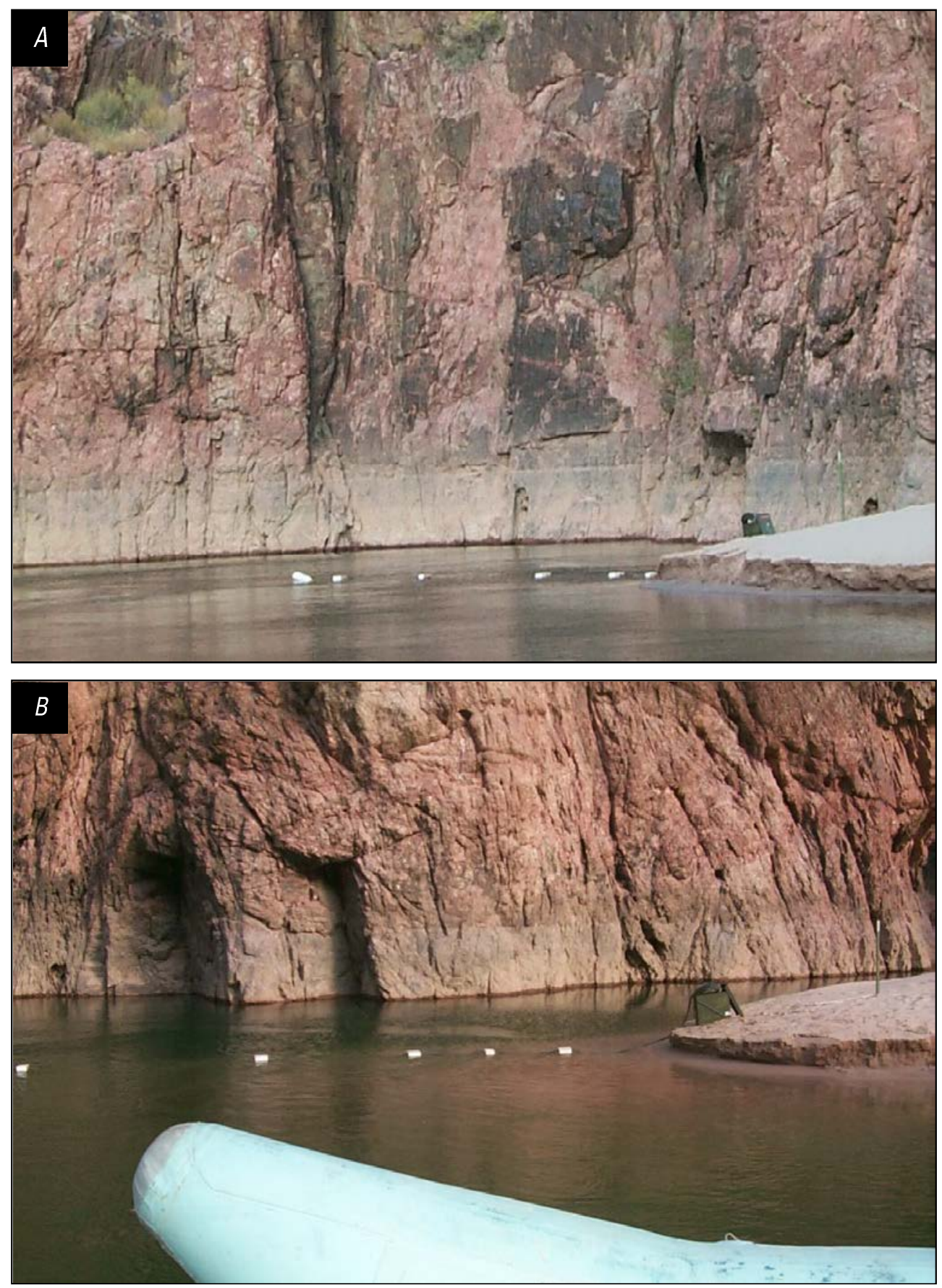

Figure 9. Photographs of the eddy site RK 141.3L and the 5-meter thermistor-string deployment for determination of nearshore temperatures in the Colorado River in Grand Canyon during the Low Steady Summer Flow experiment of 2000 looking upstream from the main channel $(A)$ and shoreward from the main channel $(B)$ (U.S. Geological Survey photographs by William S. Vernieu). 


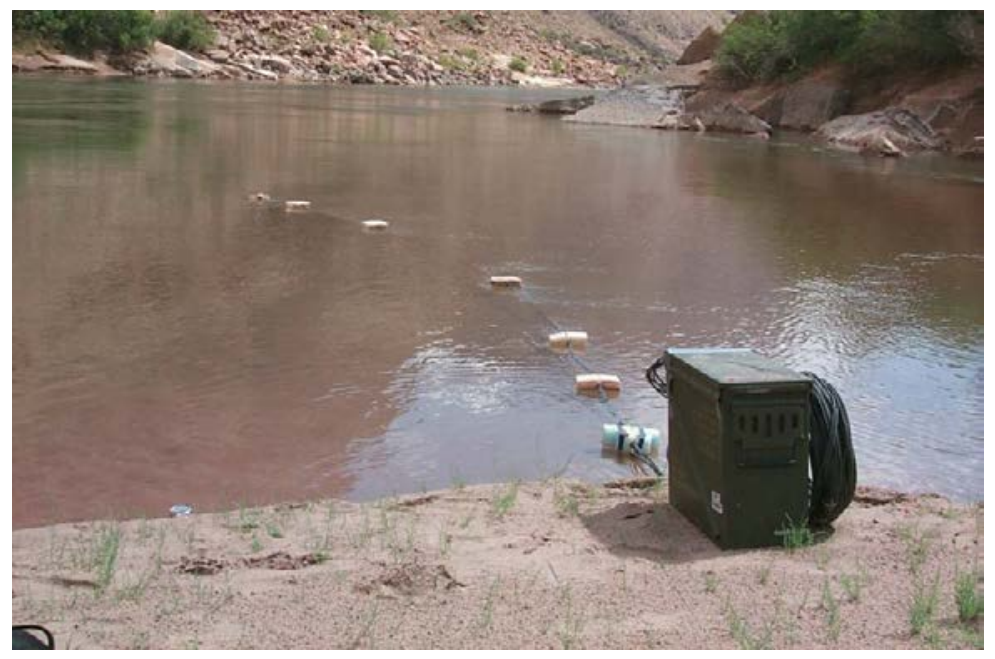

Figure 10. Photograph of the eddy site RK 226.3L and the 10-meter thermistor-string deployment for determination of nearshore temperatures in the Colorado River in Grand Canyon during the Low Steady Summer Flow experiment of 2000 (U.S. Geological Survey photograph by Harlan Taney).

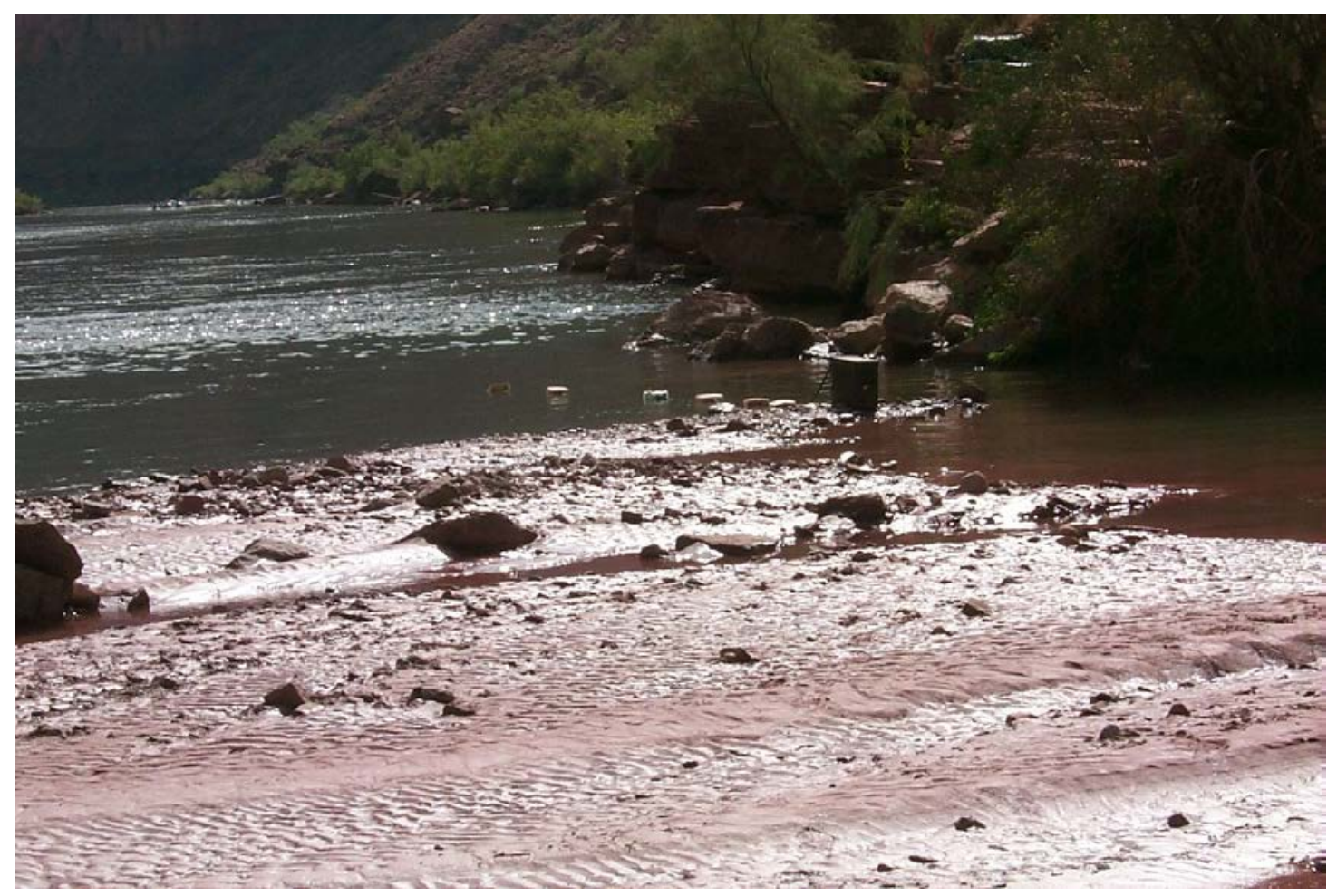

Figure 11. Photograph of the eddy site RK 231.3L looking upstream and the 5-meter thermistor-string deployment for determination of nearshore temperatures in the Colorado River in Grand Canyon during the Low Steady Summer Flow experiment of 2000 (U.S. Geological Survey photograph by Harlan Taney). 


\section{Open Channels}

For the purposes of this report, open-channel environments are defined as shallow areas along uniform shoreline margins where there are minimal physical obstructions to isolate these areas from the main-channel current. However, these environments remain well isolated from the main-channel current because of their shallow water depths and low water velocities and may exhibit enhanced nearshore warming compared to the mainstem. The substrate in these environments ranged from sand to cobbles. During this study, two open-channel environments were sampled at RK -15.9R and RK 416.2L.

\section{RK 15.9 R}

Site RK 15.9R was located on the main-channel side of a large cobble island, commonly known as Duck Island (fig. 12). The main-channel current was deflected to river left by the island, resulting in a shallow, low-velocity environment extending approximately $30 \mathrm{~m}$ into the main channel along a uniform shoreline with no constrictions or eddies immediately upstream or downstream from the site. A 15-m thermistor string was deployed for 27.5 hours at this site from August 16 to 17, 2000. Water depths ranged from $0.05 \mathrm{~m}$ at the shoreward sensor to $0.45 \mathrm{~m}$ at the end of the thermistor string.

RK 416.2L

Site RK 416.2L was located over a submerged sandbar immediately upstream of a large eddy in an open-channel environment characterized by relatively shallow water depths and low water velocities (fig. 13). A 15-m thermistor string was deployed for 19 hours at this site from August 21 to 22, 2000. Water depths ranged from $0.07 \mathrm{~m}$ at the shoreward sensor to $0.58 \mathrm{~m}$ at the end of the thermistor string.

\section{Data Processing}

For each of the thermistor strings, a Campbell Scientific CR10 datalogger was programmed to record instantaneous temperature measurements at 5-minute intervals from each sensor in the thermistor string. This interval was generally considered to be adequate for capturing short-term temperature fluctuations caused by prevailing meteorological conditions, intermittent boat traffic, and changing dam releases. On retrieval, each thermistor string and its individual temperature sensors were visually inspected for physical damage as well as configuration inconsistencies, such as separation of temperature sensors from closed-cell foam floats.

Data files were downloaded in the field from the Campbell CR10 dataloggers to a laptop computer. The raw data files were exported to text files, graphed, and visually checked for obvious errors.

Variation among temperature sensors was evaluated by deploying all four strings, each coiled to an approximate diameter of $0.5 \mathrm{~m}$ and suspended in flowing river water, on two occasions, a 14-hour overnight deployment on July 26, 2000, and a 40-minute deployment on July 30, 2000. Concurrent temperature measurements were collected from all temperature sensors and the deviation from the average value of all sensors at a given time was evaluated for each sensor. The average deviation was then calculated for each sensor. Deviations ranged from -0.10 to $0.21^{\circ} \mathrm{C}$ and were used to adjust the raw data from each sensor during the study.

Temperature data from each of the thermistor strings are available online as a comma-separatedvalues data file at http://pubs.usgs.gov/of/2013/1066/. Each record in the files is comprised of an eightcharacter Site ID, date and time, and water temperature in degrees Celsius for each sensor. 

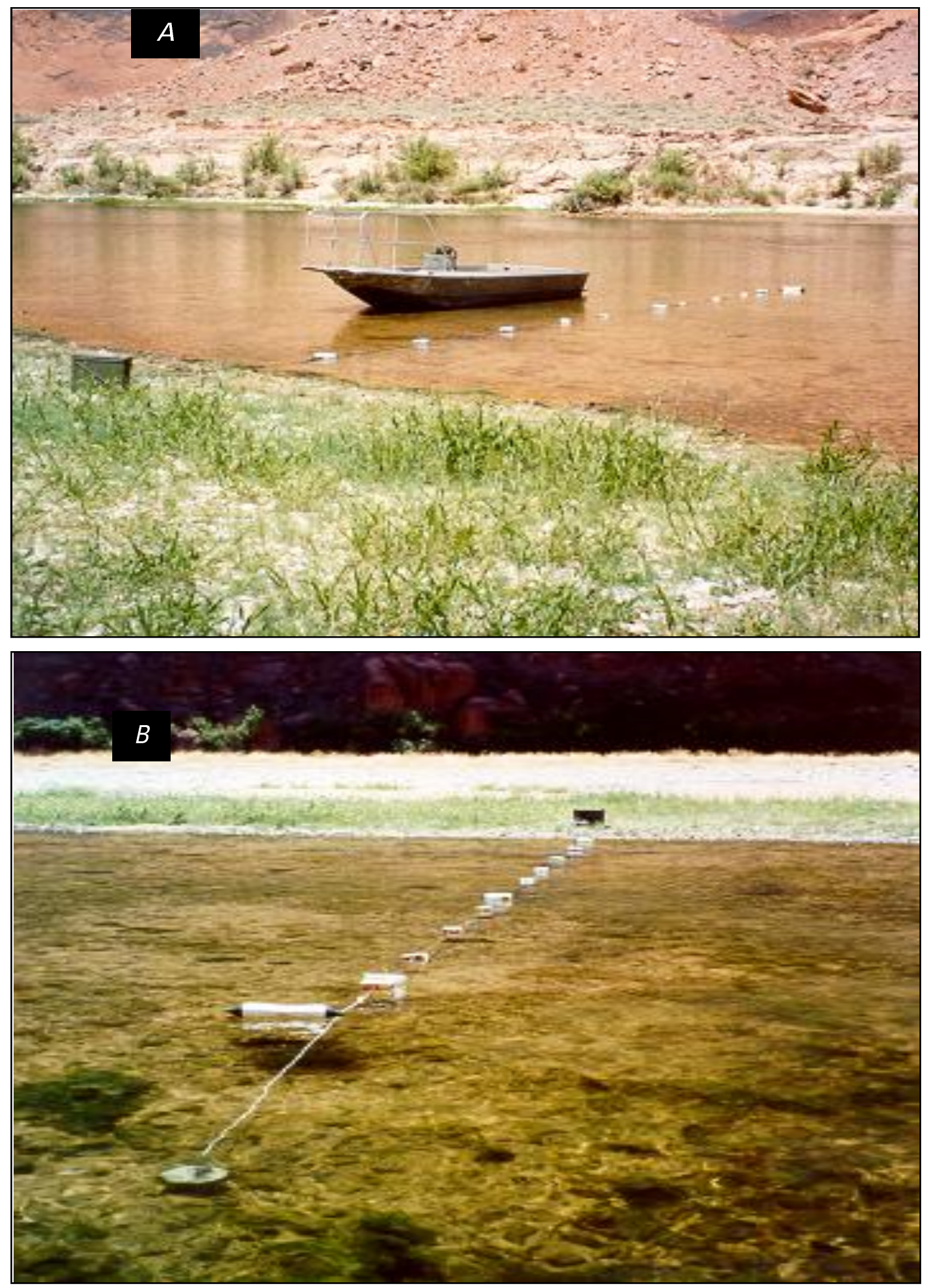

Figure 12. Photographs of the open-channel site RK $-15.9 \mathrm{R}$ and the 15-meter thermistor-string deployment for determination of nearshore temperatures in the Colorado River in Grand Canyon during the Low Steady Summer Flow experiment of 2000 looking from $(A)$ and toward $(B)$ Duck Island (U.S. Geological Survey photographs by William S. Vernieu). 

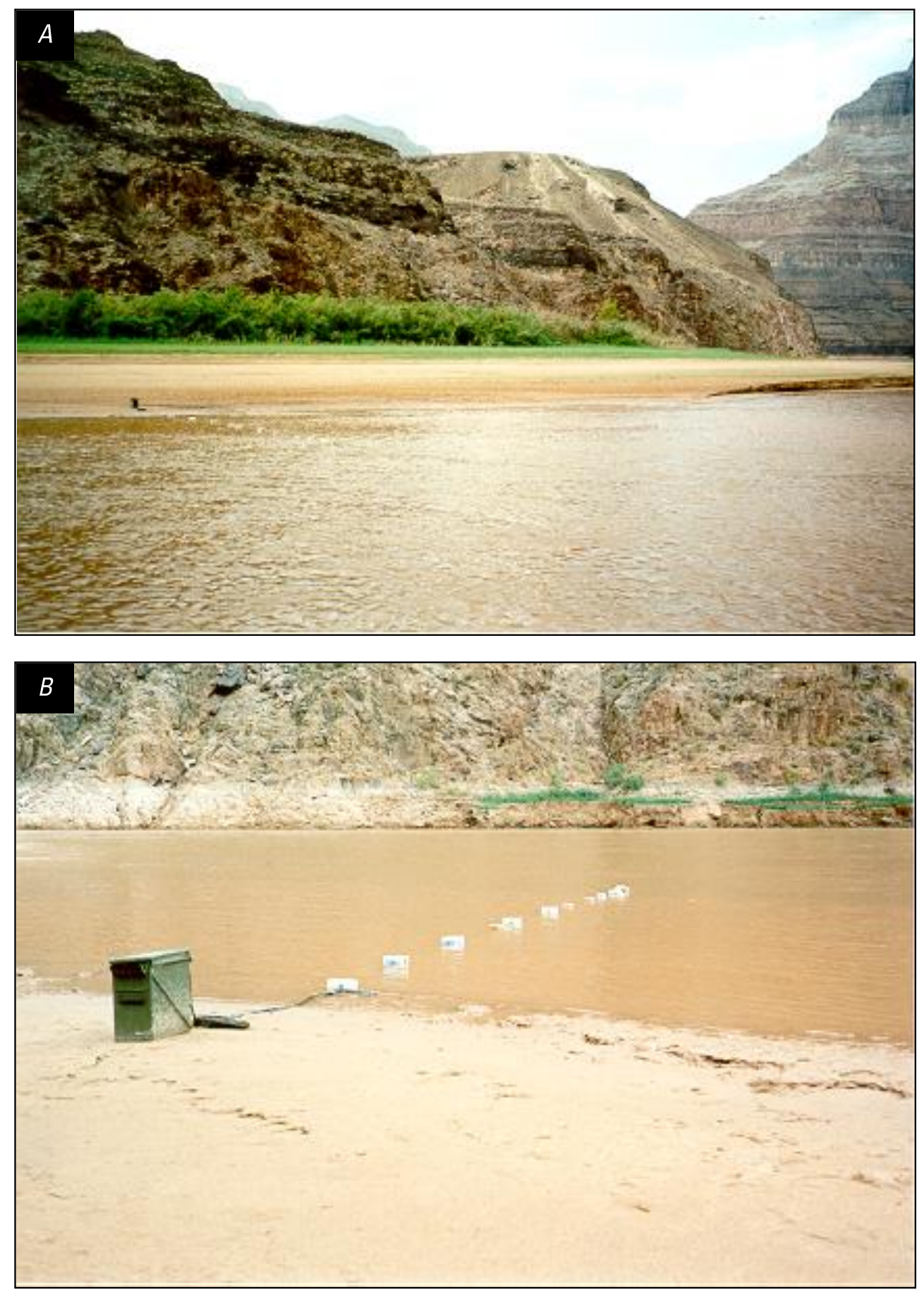

Figure 13. Photographs of the open-channel site RK 416.2L and the 15-meter thermistor-string deployment for determination of nearshore temperatures in the Colorado River in Grand Canyon during the Low Steady Summer Flow experiment of 2000 looking shoreward from the main channel $(A)$ and from the shoreline $(B)$ (U.S. Geological Survey photographs by William S. Vernieu). 


\section{Water Temperatures in Different Nearshore Areas}

Temperature data from each of the thermistor strings are presented in order of the following nearshore environment types: backwater areas, shoreline cavity areas, cobble bars, eddies, and openchannel areas. For each site, time series plots are used to show both absolute temperatures and temperature differences from the mainstem or the most distal temperature sensor. In comparisons with the mainstem, the same scale is used on the vertical axes to facilitate visual comparisons at sites with similar physical characteristics. Comparisons of water-temperature differences between individual temperature sensors and the mainstem are grouped by nearshore environment type and presented in table 4. Comparisons include the minimum and maximum daytime and nighttime temperature differences and the location relative to the shoreline where these temperatures were measured.

Table 4. Study-site type and location, daytime and nighttime minimum and maximum temperature differences from the mainstem, and the distance from the shoreline where the minimum and maximum temperature differences were recorded for determination of nearshore temperatures in the Colorado River in Grand Canyon during the Low Steady Summer Flow experiment of 2000.

[Type is the nearshore environment classification: BW, backwater; SC, shoreline cavity; CB, cobble bar (up, upstream site; down, downstream site; long, longitudinal deployment in downstream direction); ED, eddy (up, upstream site; down, downstream site); and OC, open channel. RK is river kilometers from Lees Ferry followed by side of the river looking downstream (R, right; $\mathrm{L}$, left). The daytime period (day) is from 0800 to 2000 hours, and the nighttime period (night) is from 2000 to 0800 hours. m, meters; ${ }^{\circ} \mathrm{C}$, degree Celsius]

\begin{tabular}{|c|c|c|c|c|c|c|c|c|c|}
\hline \multicolumn{2}{|c|}{ Site location } & \multicolumn{2}{|c|}{$\begin{array}{c}\text { Minimum } \\
\text { temperature } \\
\text { difference } \\
\left({ }^{\circ} \mathrm{C}\right)\end{array}$} & \multicolumn{2}{|c|}{$\begin{array}{l}\text { Distance from } \\
\text { shoreline } \\
(\mathrm{m})\end{array}$} & \multicolumn{2}{|c|}{$\begin{array}{c}\text { Maximum } \\
\text { temperature } \\
\text { difference } \\
\left({ }^{\circ} \mathrm{C}\right)\end{array}$} & \multicolumn{2}{|c|}{$\begin{array}{l}\text { Distance from } \\
\text { shoreline } \\
(\mathrm{m})\end{array}$} \\
\hline Type & RK & Day & Night & Day & Night & Day & Night & Day & Night \\
\hline BW & $141.6 \mathrm{R}$ & 0.1 & 0.0 & 27 & 27 & 13.0 & 3.5 & 2 & 2 \\
\hline $\mathrm{SC}$ & $104.6 \mathrm{~L}$ & 0.2 & 0.1 & 10 & 2 & 4.1 & 0.8 & 1 & 1 \\
\hline CB-up & $325.9 \mathrm{R}$ & 0.0 & 0.0 & 3 & 3 & 2.8 & 0.4 & 0.5 & 0.5 \\
\hline CB-down & $325.9 \mathrm{R}$ & 0.0 & 0.0 & 10 & 5 & 4.8 & 0.8 & 1 & 1 \\
\hline CB-long & $325.9 \mathrm{R}$ & 0.0 & 0.0 & 2 & 2 & 0.6 & 0.1 & 2 & 2 \\
\hline ED & $102.2 \mathrm{~L}$ & 0.3 & 0.2 & 2 & 2 & 1.3 & 0.1 & 5 & 5 \\
\hline ED & $141.1 \mathrm{~L}$ & 0.1 & 0.1 & 5 & 5 & 1.9 & 0.7 & 1 & 0.5 \\
\hline ED & $141.3 \mathrm{~L}$ & 0.0 & 0.1 & 3 & 10 & 0.2 & 0.1 & 1 & 10 \\
\hline ED-up & $221.3 \mathrm{~L}$ & 0.3 & 0.0 & 1 & 2 & 1.5 & 0.4 & 1 & 1 \\
\hline ED-down & $221.3 \mathrm{~L}$ & 0.0 & 0.0 & 1 & 5 & 2.2 & 0.3 & 1 & 1 \\
\hline ED & $226.3 \mathrm{~L}$ & 0.0 & 0.0 & 1 & 1 & 1.0 & 0.2 & 1 & 1 \\
\hline ED & $231.3 \mathrm{~L}$ & 0.2 & 0.0 & 1 & 2 & 0.6 & 0.2 & 3 & 1 \\
\hline $\mathrm{OC}$ & $15.9 \mathrm{R}$ & 0.3 & 0.0 & 10 & 10 & 7.6 & 4.4 & 1 & 1 \\
\hline $\mathrm{OC}$ & $416.2 \mathrm{~L}$ & 0.0 & 0.1 & 5 & 10 & 5.0 & 1.0 & 3 & 1 \\
\hline
\end{tabular}




\section{Backwater Areas}

The most warming recorded during the study $\left(13.0^{\circ} \mathrm{C}\right.$ above mainstem temperature $)$ occurred at the isolated backwater site RK 141.6R (fig. 14), which was approximately $30 \mathrm{~m}$ in length, closed on three sides, and situated parallel to the river channel. As such, there was very little exchange between the mainstem and most of the backwater. Further isolation of the sensors closest to shore was provided by a growth of aquatic vegetation in a shallow zone near the terminal end of the backwater, a situation which also assisted in maintaining nighttime minimum temperatures above that of the mainstem.

\section{Shoreline-Cavity Areas}

A lesser amount of warming was measured at the shoreline-cavity site RK 104.6L (fig. 15). Approximately $3-4^{\circ} \mathrm{C}$ warming was measured at this site. Although the shoreline cavity provided isolation of the nearshore sensors from the main-channel current at this site, no discernible warming was noted $10 \mathrm{~m}$ from shore. In addition, as this site was open to the main channel, substantial fluctuations in the nearshore temperatures were observed, most likely from mixing caused by boat traffic.

\section{Cobble-Bar Areas}

Warming of approximately $2-3^{\circ} \mathrm{C}$ at the upper cobble-bar site and $4-5^{\circ} \mathrm{C}$ at the lower cobble-bar site was measured at RK 325.9R (figs. 16 and 17). These thermistor strings were situated perpendicular to the shoreline. The broad shallow area of the cobble bar and the irregular substrate provided sufficient ponding of water and isolation from the current to achieve the observed warming. The lower site, situated approximately $20 \mathrm{~m}$ downstream of the upper site, was located immediately above a section of the cobble bar that protruded into the river, forming a downstream terminus to the small involution of the shoreline at this site. Therefore, the ponding of water caused by this protrusion may explain the increased amount of warming measured at the lower site compared to the upper site, which did not have any major barriers to current moving through the cobble-bar area.

The longitudinal deployment at RK 325.9R showed less than $1^{\circ} \mathrm{C}$ of warming (fig. 18). However, the amount of warming in this case was calculated by the temperature differences between the individual sensors and the 27-m sensor, because there was no independent mainstem temperature measurement. Therefore, actual warming above the mainstem may have been closer to $2^{\circ} \mathrm{C}$, which is still comparatively small. The lack of substantial warming at this site is most likely because of excessive current flowing through the cobble-bar area. However, it is interesting to note that the sensors in the middle of the longitudinal string, which were farther from shore in the small shoreline embayment, recorded the lowest temperatures.

\section{Eddies}

Little warming (less than $2.2^{\circ} \mathrm{C}$ ) was measured at most of the eddy sites (figs. 19-25) and no perceptible warming was measured at RK 141.3L (fig. 21). In most of these cases, there was insufficient isolation from the current (see fig. 10, photograph showing the deflection of the thermistor string by the eddy current at RK 226.3L) to provide appreciable warming, except at sites RK 141.1L (fig. 20) and RK 221.3 (fig. 23), where 1.9 and $2.2^{\circ} \mathrm{C}$ of warming were measured, respectively. The sensors that did record warming were located in more quiescent water and were more isolated from exchange with the mainstem. 


\section{Open-Channel Areas}

Warming of $7.6^{\circ} \mathrm{C}$ was measured at open-channel site $\mathrm{RK}-15.9 \mathrm{~L}$ (fig. 26) and $5.0^{\circ} \mathrm{C}$ at openchannel site RK 416.2L (fig. 27). At RK -15.9L, the shoreward areas from 1 to $5 \mathrm{~m}$ retained heat during the night and substantial warming was recorded throughout the daylight hours. At RK 416.2L, most sensors recorded temperatures similar to those of the mainstem during the night, except for the 1-m sensor, which only recorded temperatures slightly above those of the mainstem. In addition, the duration of warming was substantially reduced at this site, although this may have been due to turbulent mixing of the nearshore environment from boat disturbance on arrival at the site. Channel morphology and flow patterns could account for major differences in warming patterns between these sites. RK $-15.9 \mathrm{~L}$ represented a long straight run of river, and conditions were much more quiescent at that site, whereas RK 416.2L may have been affected by the large eddy located a short distance downstream and more turbulent water. The amount of warming at the downstream location may have been less because the river was much warmer and there was not as much difference between the water temperature and ambient air temperature.

Although there was no physical barrier between these sites and the main-channel current, the river channel was wide at both sites and thermistor-string deployments were located in shallow water on the inside of large bends in the channel. In general, these low-velocity environments provided the isolation from the main-channel current that resulted in the warming patterns. 

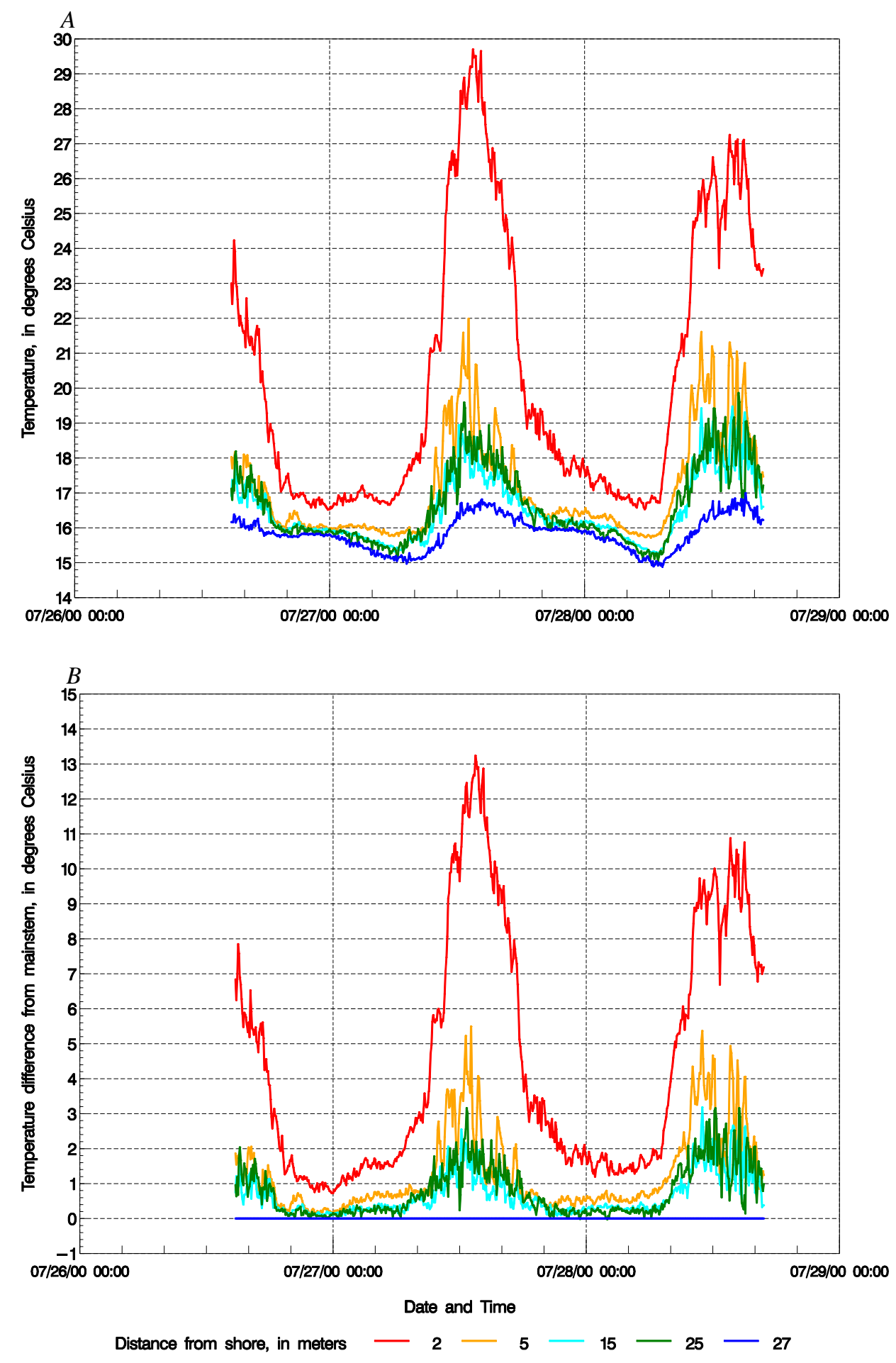

Figure 14. Graphs showing lateral water-temperature patterns $(A)$ and differences from mainstem temperature $(B)$ for the backwater site RK 141.6R along the Colorado River in Grand Canyon during the Low Steady Summer Flow experiment of 2000 (see fig. 4 for photographs of the site). 

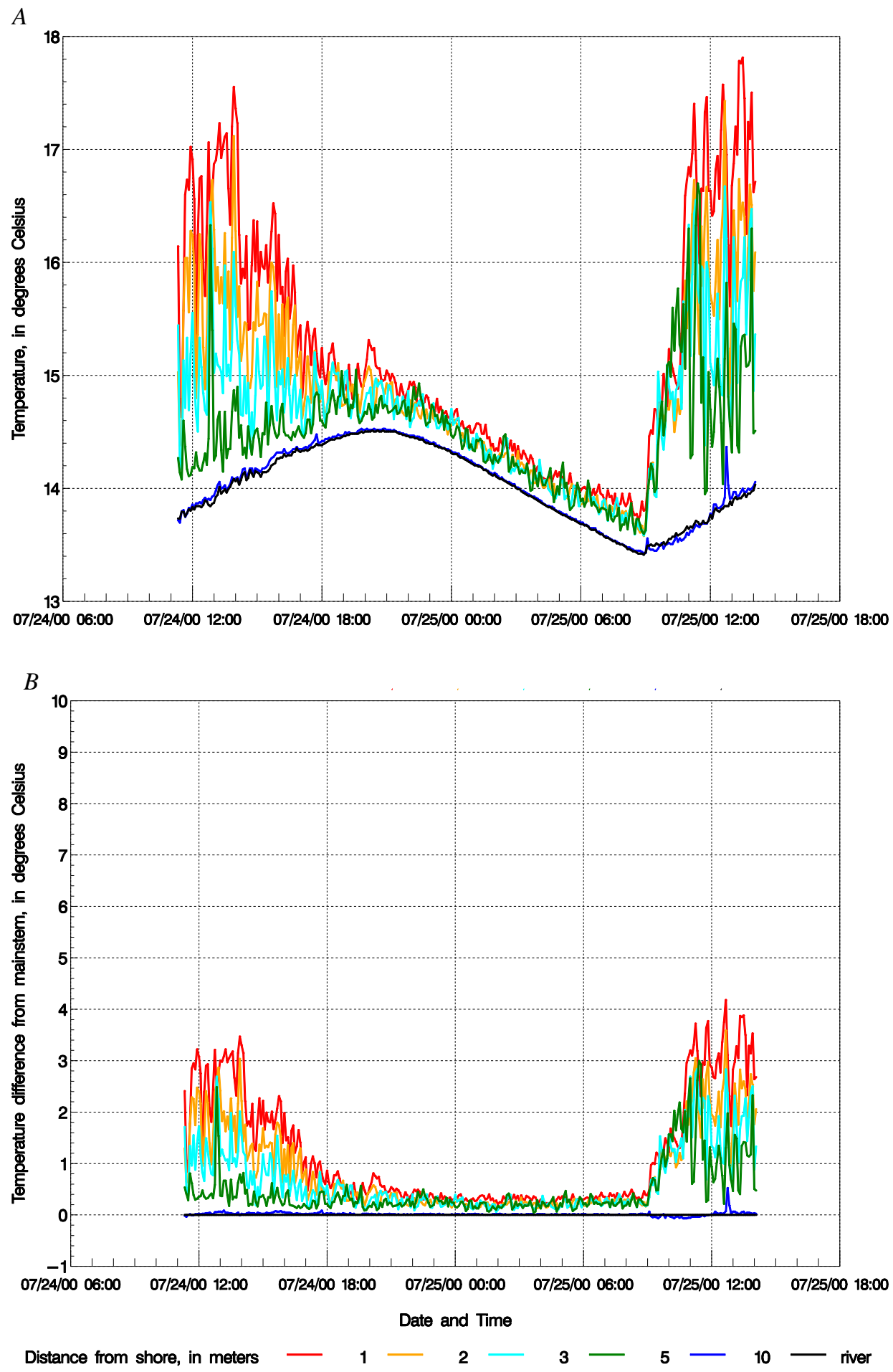

Figure 15. Graphs showing lateral water temperature patterns $(A)$ and differences from mainstem temperature $(B)$ for the shoreline cavity site RK 104.6L along the Colorado River in Grand Canyon during the Low Steady Summer Flow experiment of 2000 (see fig. 5 for photographs of the site). 

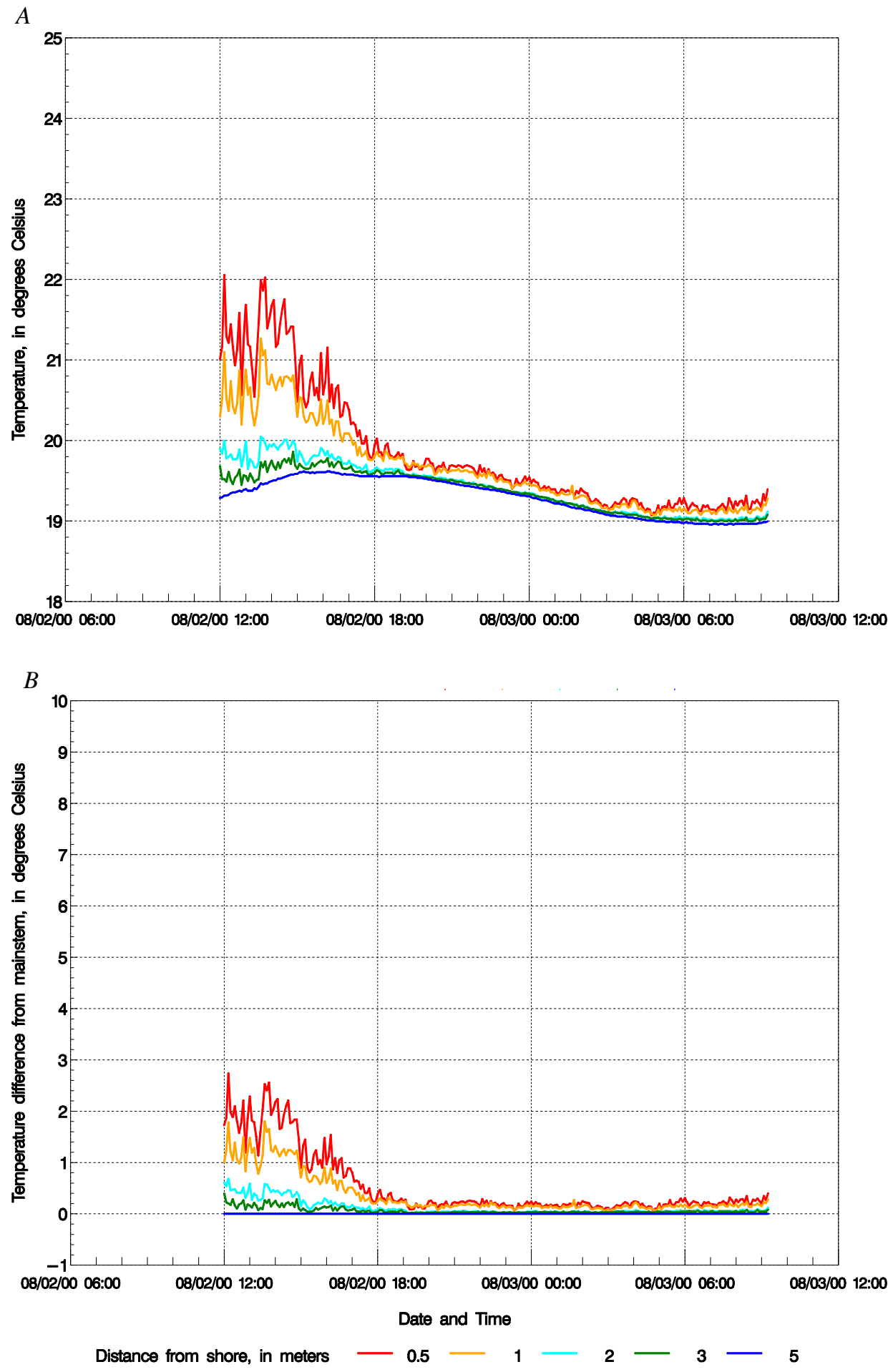

Figure 16. Graphs showing lateral water-temperature patterns $(A)$ and differences from mainstem temperature $(B)$ for the cobble-bar upper site RK 325.9R along the Colorado River in Grand Canyon during the Low Steady Summer Flow experiment of 2000 (see fig. 6 for photographs of the site). 

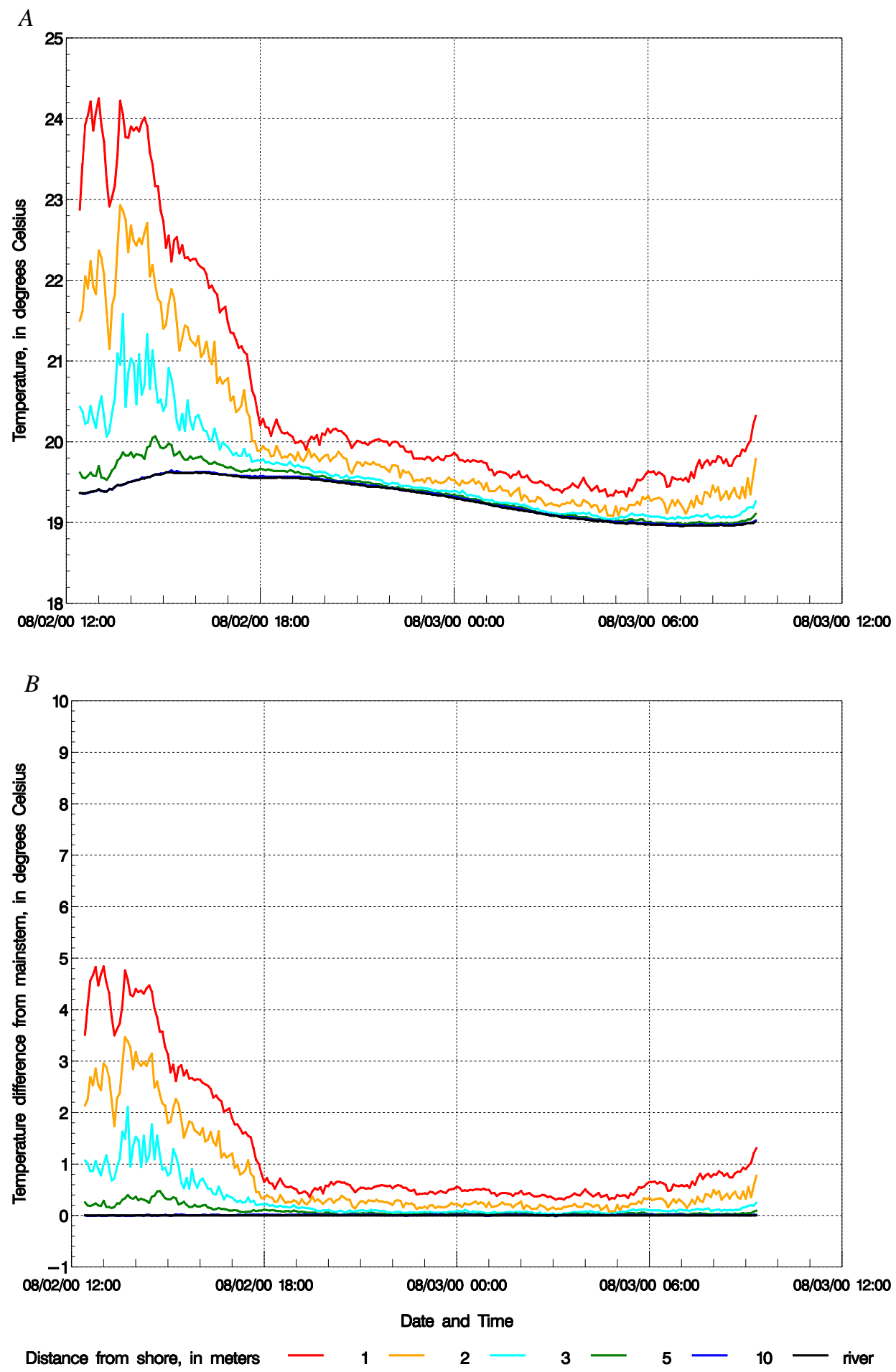

Figure 17. Graphs showing lateral water-temperature patterns $(A)$ and differences from mainstem temperature $(B)$ for the cobble-bar lower site RK 325.9R along the Colorado River in Grand Canyon during the Low Steady Summer Flow experiment of 2000 (see fig. 6 for photographs of the site). 

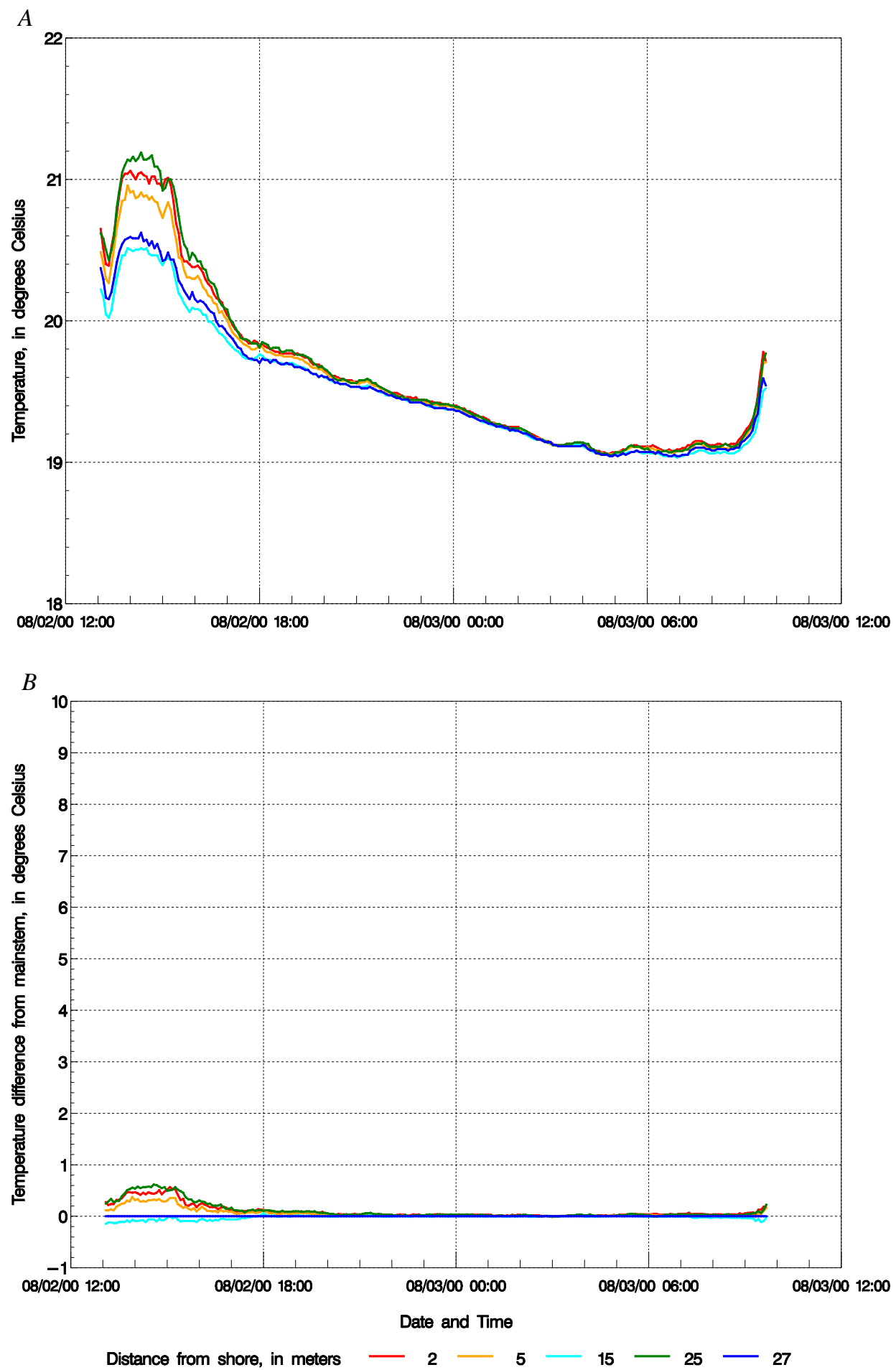

Figure 18. Graphs showing lateral water-temperature patterns $(A)$ and differences from mainstem temperature $(B)$ for the cobble-bar longitudinal site RK 325.9R along the Colorado River in Grand Canyon during the Low Steady Summer Flow experiment of 2000; 27-m sensor used as surrogate for mainstem temperature (see fig. 6 for photographs of the site). 

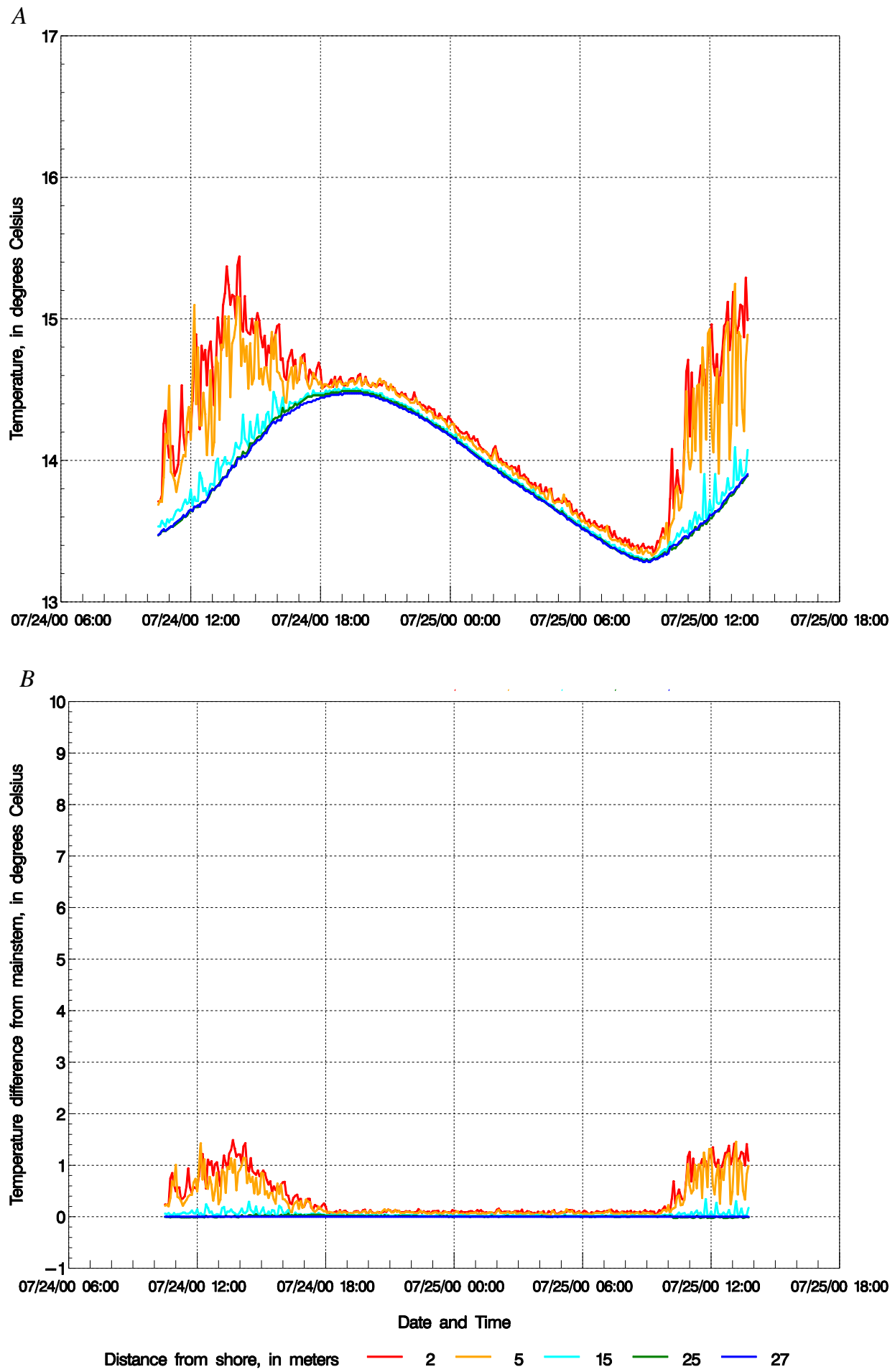

Figure 19. Graphs showing lateral water-temperature patterns $(A)$ and differences from mainstem temperature $(B)$ for the eddy site RK 102.2L along the Colorado River in Grand Canyon during the Low Steady Summer Flow experiment of 2000 (see fig. 7 for photograph of the site). 

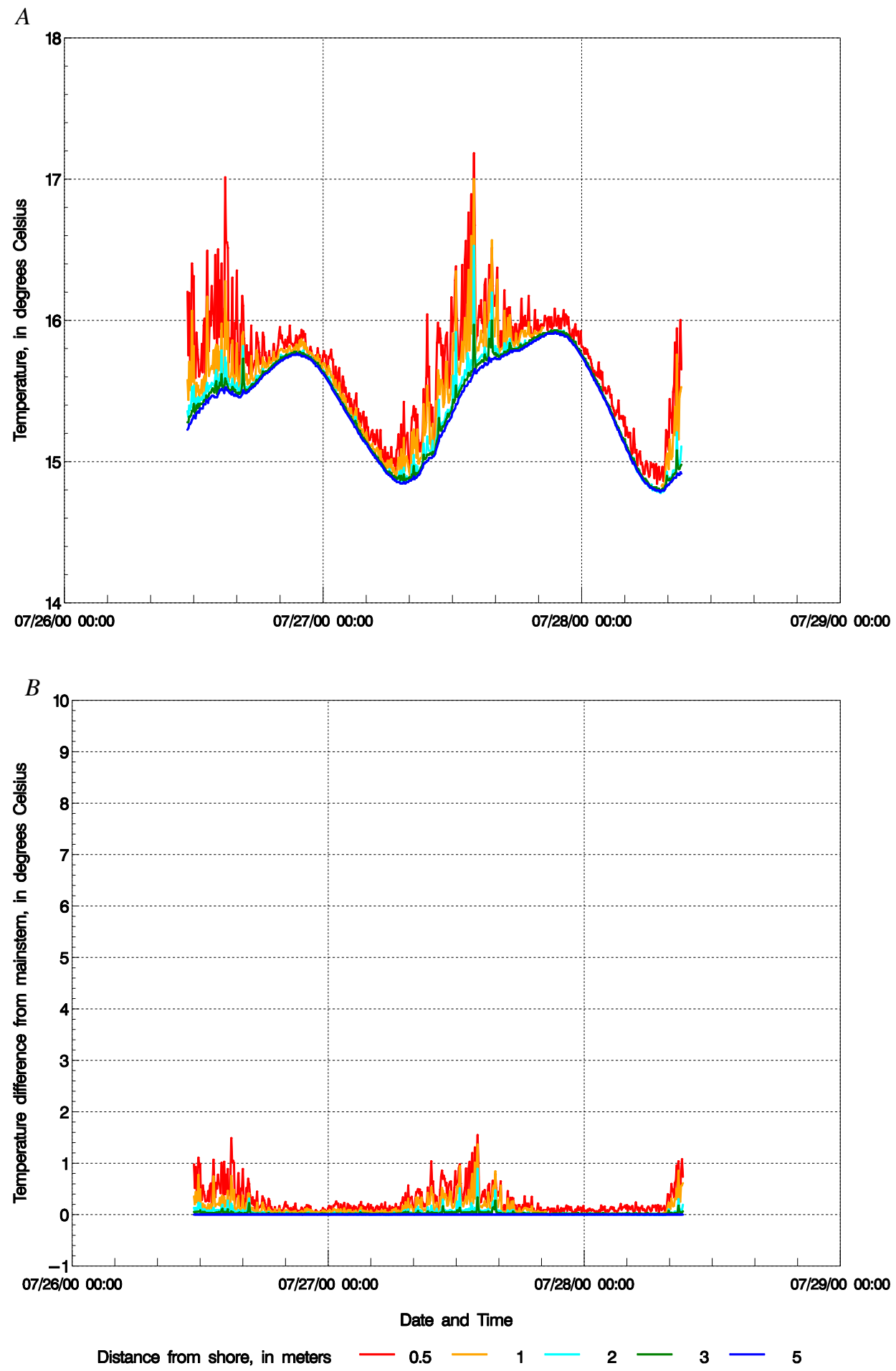

Figure 20. Graphs showing lateral water-temperature patterns $(A)$ and differences from mainstem temperature $(B)$ for the eddy site RK 141.1L along the Colorado River in Grand Canyon during the Low Steady Summer Flow experiment of 2000 (see fig. 8 for photograph of the site). 

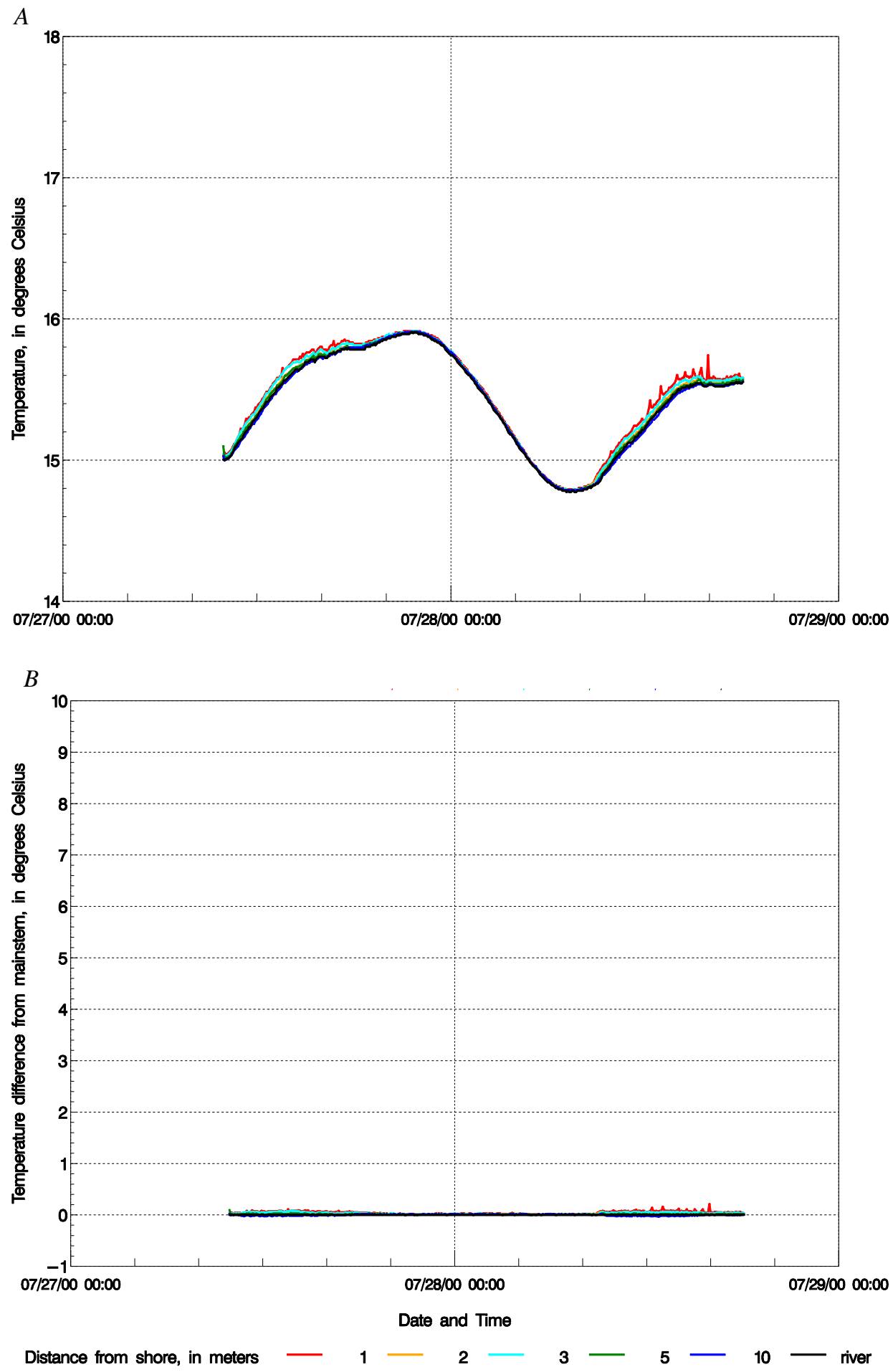

Figure 21. Graphs showing lateral water-temperature patterns $(A)$ and differences from mainstem temperature $(B)$ for the eddy site RK 141.3L along the Colorado River in Grand Canyon during the Low Steady Summer Flow experiment of 2000 (see fig. 9 for photographs of the site). 

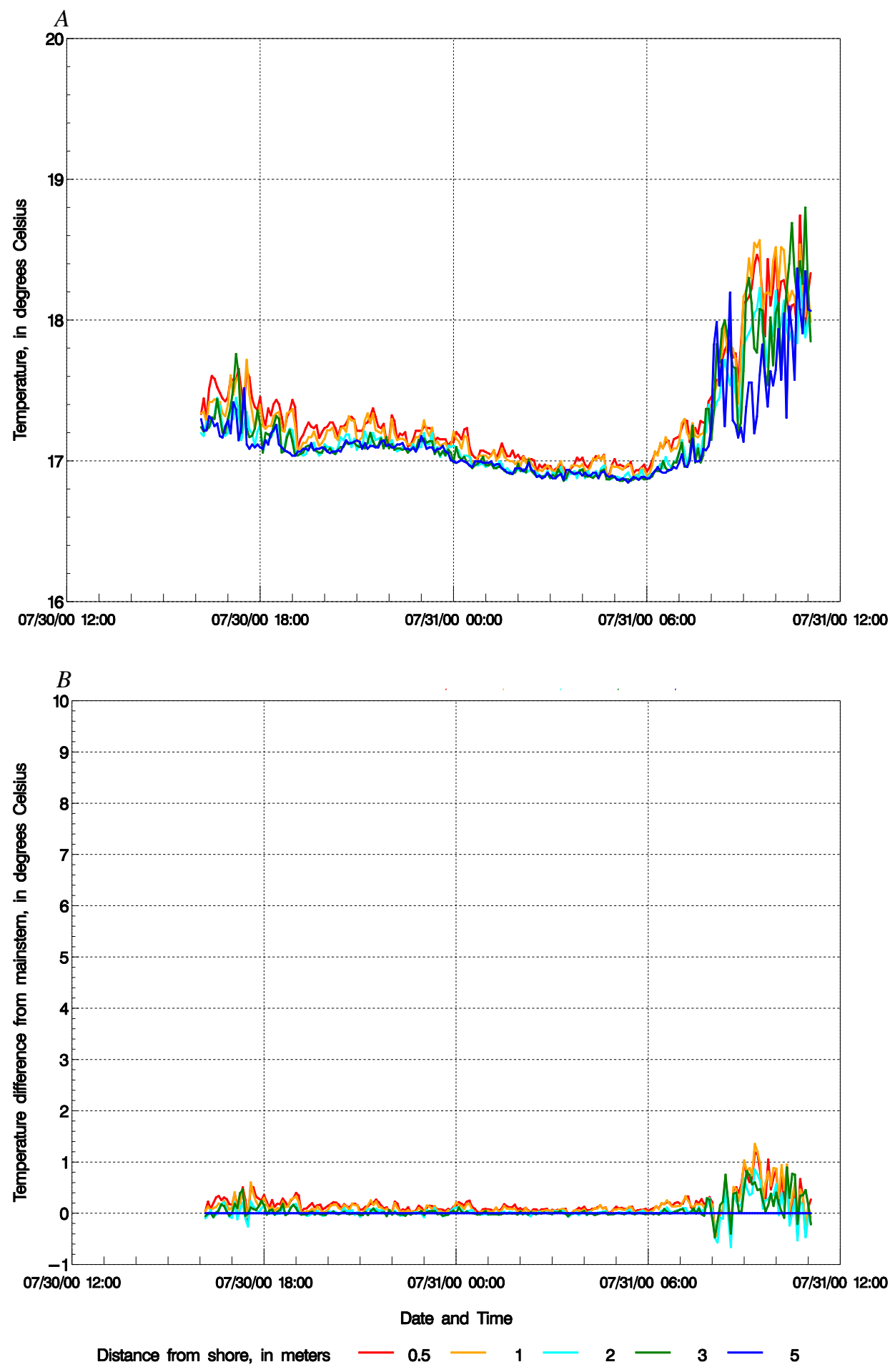

Figure 22. Lateral water-temperature patterns $(A)$ and differences from mainstem temperature $(B)$ for the upper eddy site RK 221.3L along the Colorado River in Grand Canyon during the Low Steady Summer Flow experiment of 2000. 

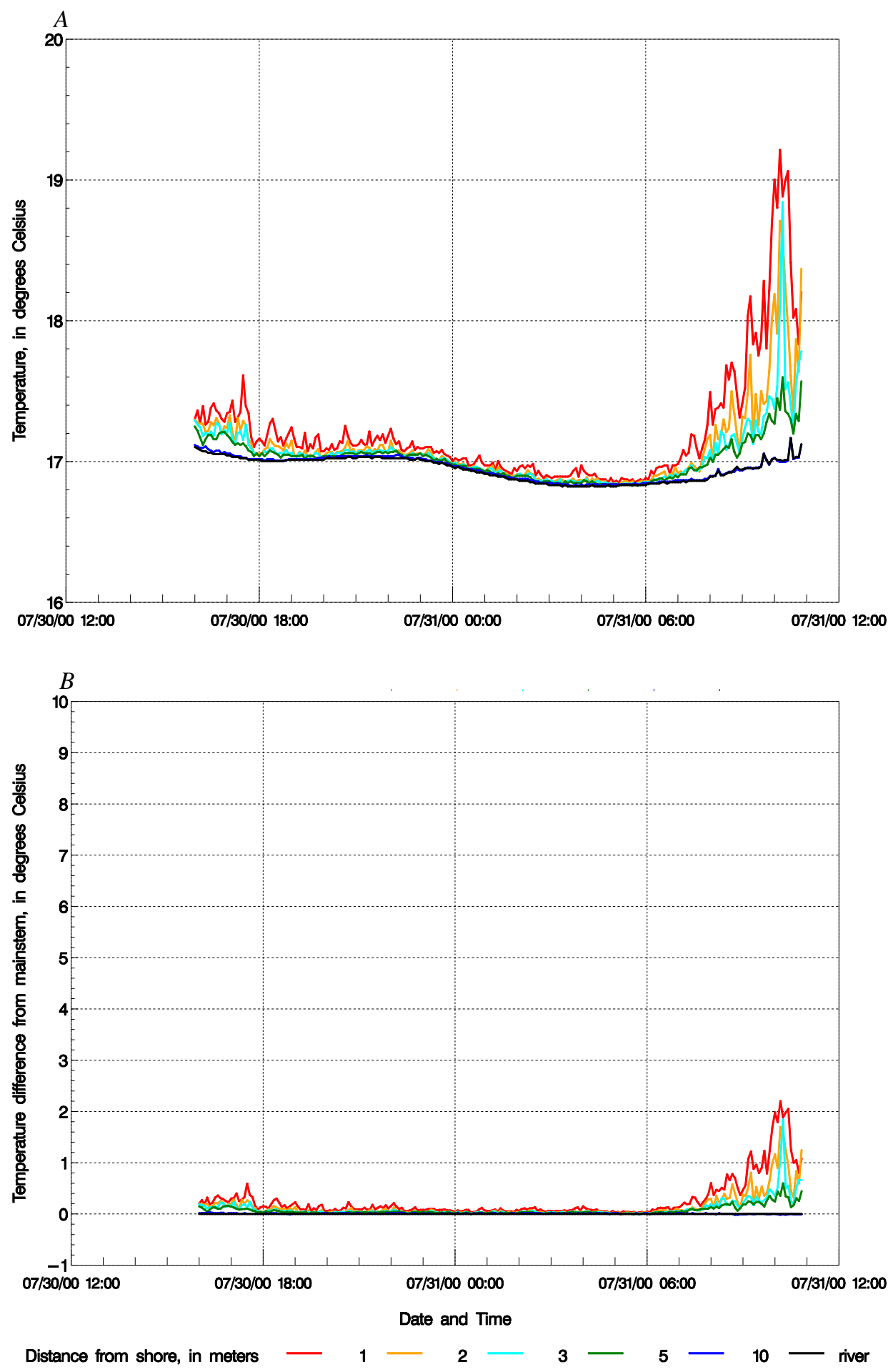

Figure 23. Graphs showing lateral water-temperature patterns $(A)$ and differences from mainstem temperature $(B)$ for the lower eddy site RK 221.3L along the Colorado River in Grand Canyon during the Low Steady Summer Flow experiment of 2000. 

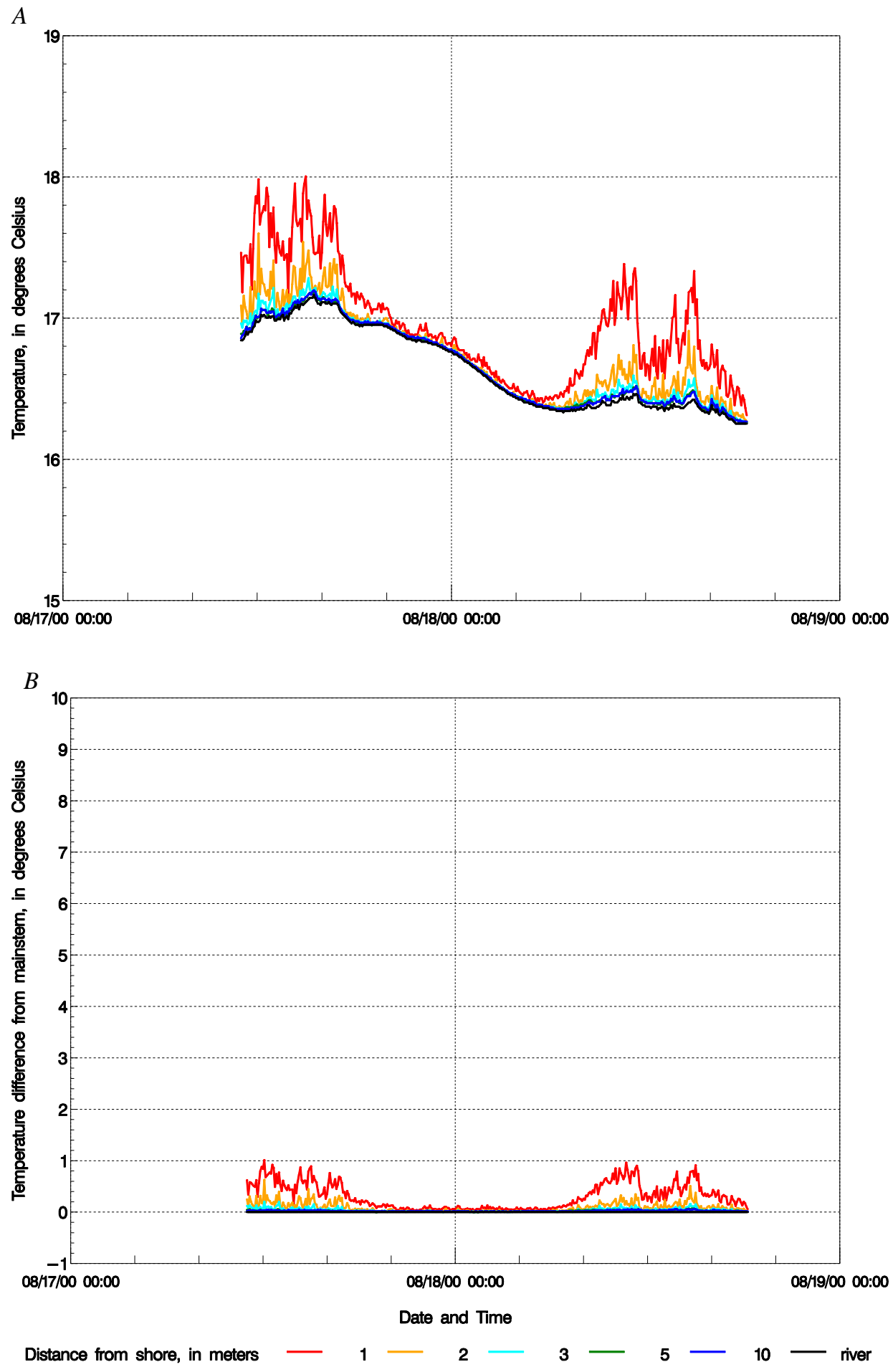

Figure 24. Graphs showing lateral water-temperature patterns $(A)$ and differences from mainstem temperature $(B)$ for the eddy site RK 226.3L along the Colorado River in Grand Canyon during the Low Steady Summer Flow experiment of 2000 (see fig. 10 for photograph of the site). 

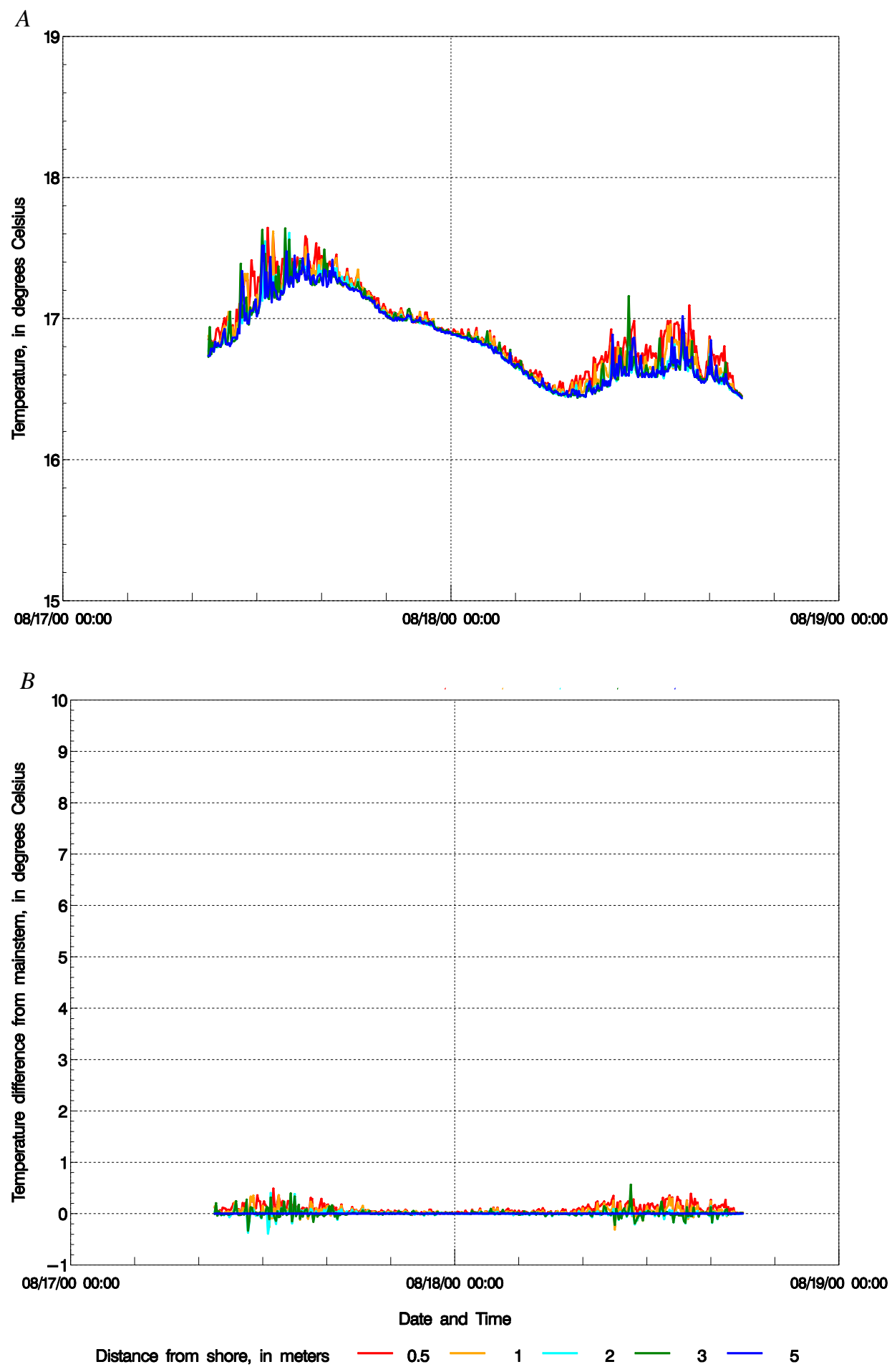

Figure 25. Graphs showing lateral water-temperature patterns $(A)$ and differences from mainstem temperature $(B)$ for the eddy site RK 231.3L along the Colorado River in Grand Canyon during the Low Steady Summer Flow experiment of 2000 (see fig. 11 for photograph of the site). 

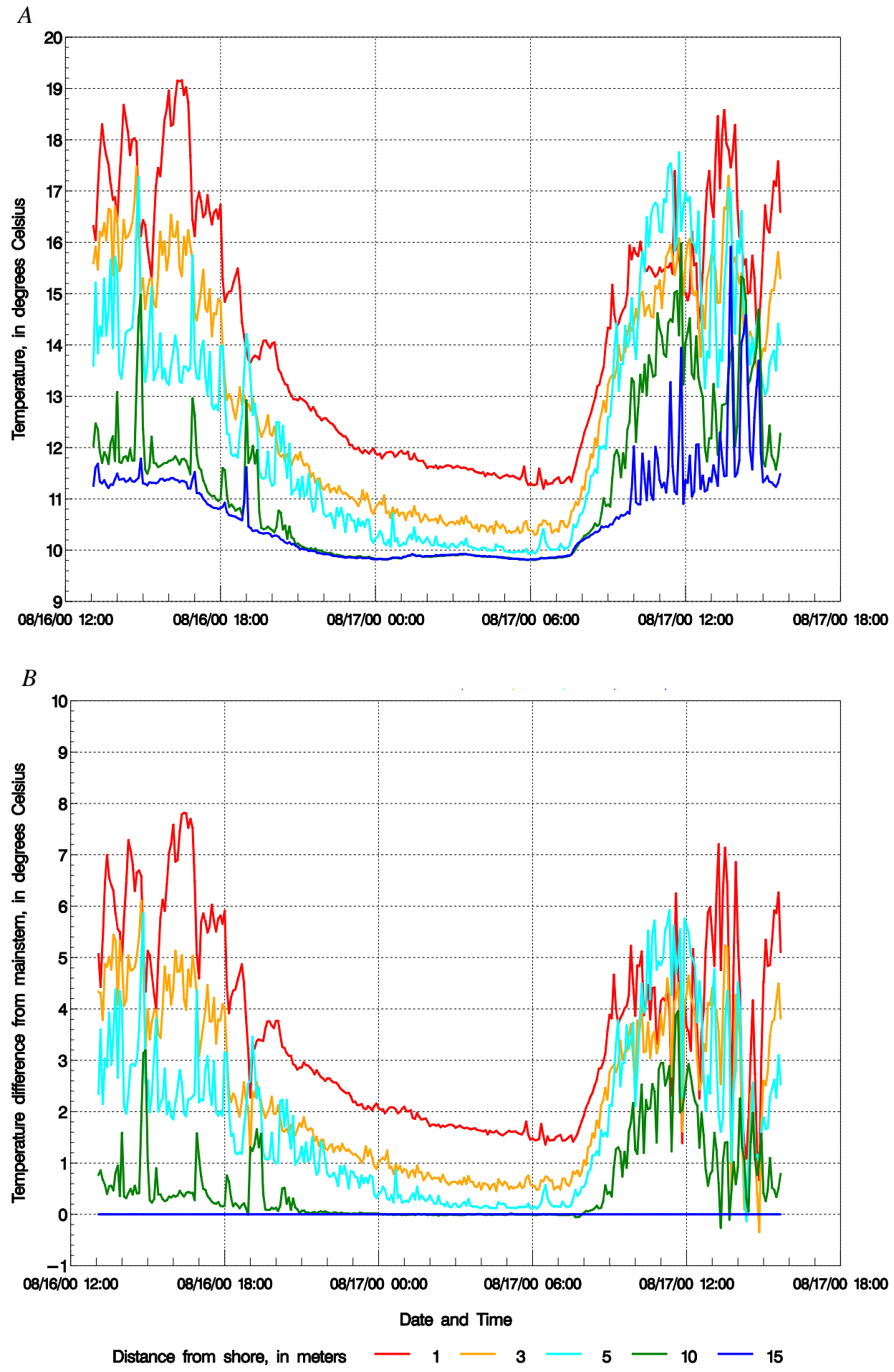

Figure 26. Graphs showing lateral water-temperature patterns $(A)$ and differences from mainstem temperature $(B)$ for the open-channel site RK -15.9 R along the Colorado River in Grand Canyon during the Low Steady Summer Flow experiment of 2000 (see fig. 12 for photographs of the site). 

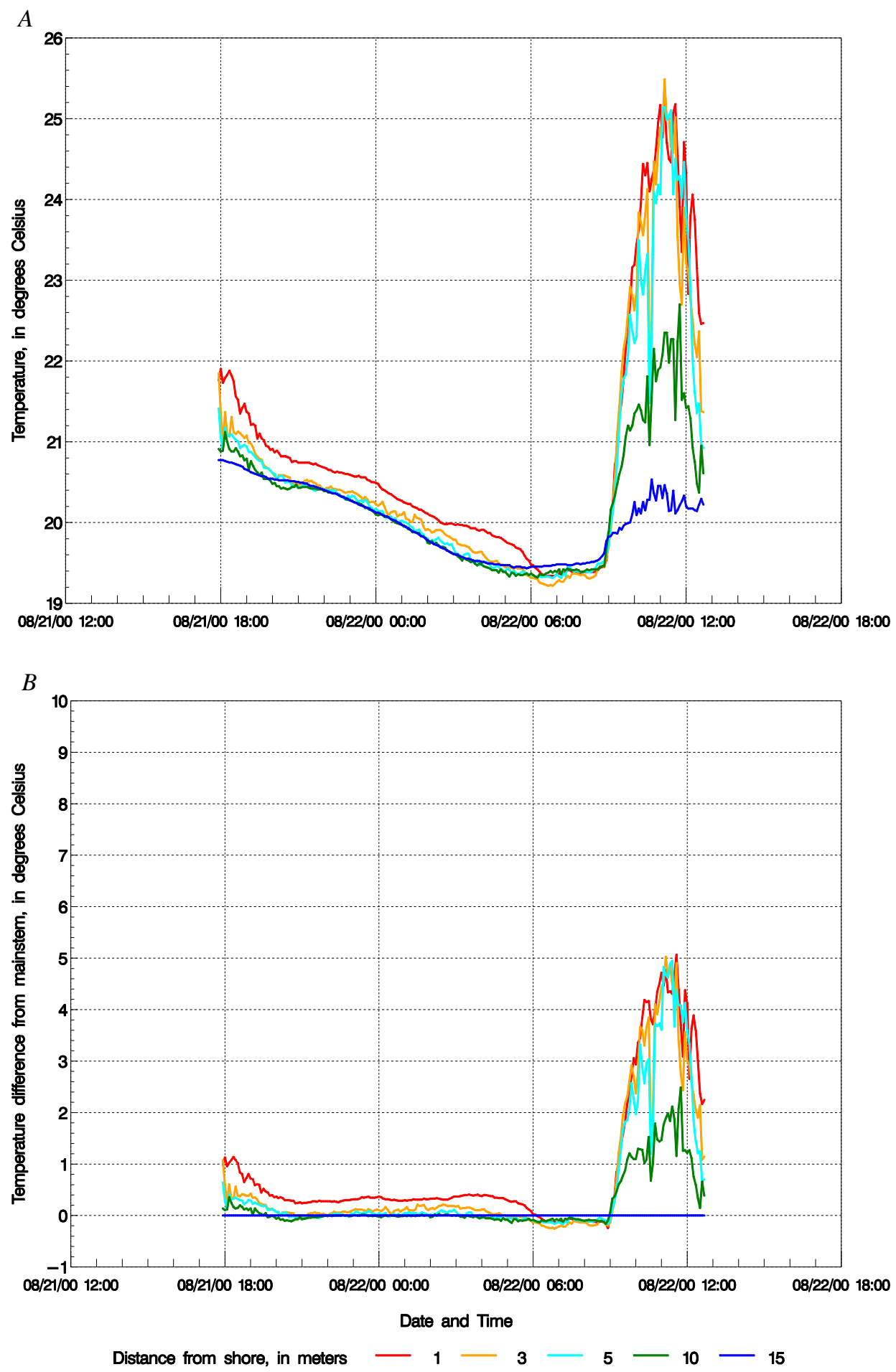

Figure 27. Graphs showing lateral water-temperature patterns $(A)$ and differences from mainstem temperature $(B)$ for the open-channel site RK 416.2L along the Colorado River in Grand Canyon during the Low Steady Summer Flow experiment of 2000 (see fig. 13 for photographs of the site). 


\section{Differences in Warming Among Sites}

Comparison of the time-series plots among different environments shows, in general, a relation between diurnal warming of the nearshore environment and the degree of isolation from the mainchannel current. Additionally, the most significant warming occurred during the day and only with direct solar radiation. Maximum warming occurred at the isolated backwater at RK 141.6R, which offered very little exchange with the mainstem current, especially at its terminal end. At sites where there was a perceptible current, minimal or no warming occurred. Furthermore, warming only occurred during periods of direct solar radiation. During these periods, warming occurred as a fairly sharp rise in the time-series plots in the morning hours, corresponding to the onset of incident solar radiation at each site. After the sun dropped below the horizon, the sensors cooled at a slower rate because of the residual heat of the water, warm ambient air temperature, and the slow rate of mixing with surrounding water. Except for the most isolated sensors, the thermistor-string temperatures gradually returned to those of the main channel through mixing and heat-transfer processes, once the site was no longer in direct sunlight.

At many of the sites, most notably RK 104.6L (fig. 15), the nearshore sensors that recorded warming above the main channel fluctuated greatly throughout the daylight hours. This appears to be the result of cold, main-channel water moving into the site from wave action caused by wind or boat traffic. The effect was magnified at this site by the shoreline cavity's direct exposure to the main channel. A similar pattern was observed at RK 141.1L (fig. 20). The small amount of warming measured in the nearshore sensors was repeatedly cooled by disturbances from boat and foot traffic near Cremation Camp (fig. 8). At RK 416.2L (fig. 27), arrival of a boat at the site, and subsequent mixing of the water, may also explain the cessation of daytime warming that was observed shortly before noon, approximately 30 minutes before the thermistor string was removed.

\section{Warming in Other Nearshore Areas in Grand Canyon}

Temperature measurements were made during this study to provide examples of the potential for warming of various types of nearshore environments in selected reaches of the Colorado River ecosystem between GCD and Lake Mead. The measurements were not intended to quantify the amount of warming that can occur in all habitats throughout the river corridor. Another approach to measure the areal extent of nearshore warming could involve the use of airborne thermal-infrared imagery. Coincident with the thermistor-string deployment at site RK 104.6, a study was conducted using airborne thermal-infrared imagery in a small part of the river corridor near the mouth of the Little Colorado River on July 25, 2000 (Davis, 2002). A thermal-infrared image of the area that includes the RK 104.6 shoreline-cavity site shows warming in this shoreline cavity, along the channel margins of the river, and in shallow nearshore areas downstream of this site (fig. 28). Although the spatial area of that study was limited and the airborne thermal-infrared sensor was calibrated for a very wide range of terrestrial and aquatic temperatures, there could be much value in refinement of this technology to quantify the areal extent of nearshore warming throughout the river corridor. 


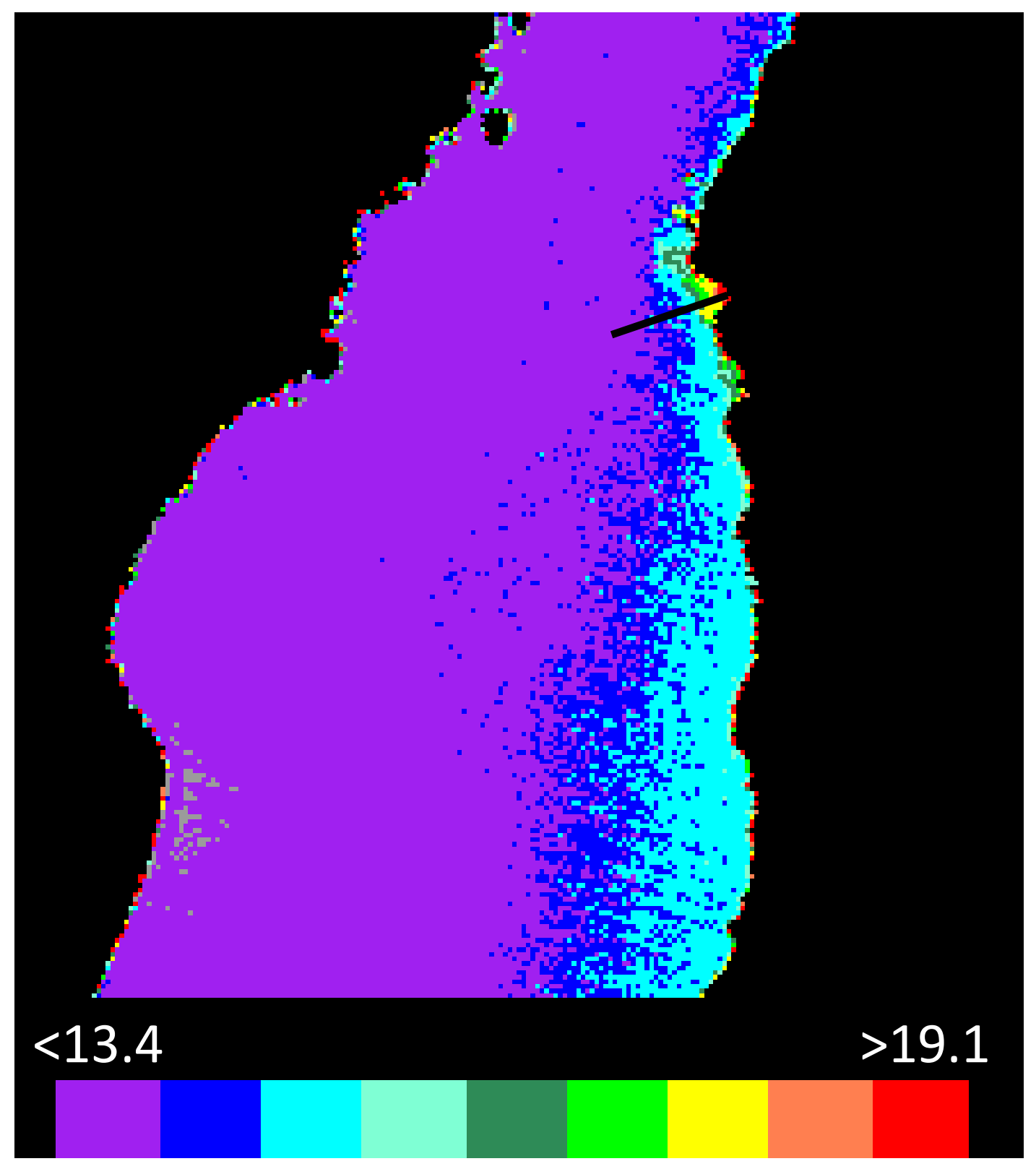

Figure 28. Aerial thermal-infrared image of water-surface temperature of shoreline-cavity site RK104.6L on July 25, 2000 (from Davis, 2002). Color band is scaled in degrees Celsius. Approximate location of thermistor string deployed from July 24,2000 , to July 25,2000 , is shown by black line. 


\section{Conclusions}

The temperature data collected during this study confirm that warming of nearshore environments in the Colorado River in Grand Canyon does occur during steady discharge from GCD, depending on the degree of isolation from main-channel influences and the amount of solar radiation. Except for the most isolated environments, all nearshore temperatures return to those of the main channel after daytime solar-radiation inputs cease, regardless of the amount of isolation from the mainchannel current. Therefore, any warming of the nearshore environments during steady discharge is ephemeral and is likely to be absent during cloudy or extremely windy conditions.

\section{Acknowledgments}

The authors would like to recognize and thank the following people who assisted in the field data collection efforts: Dennis Harris, Stuart Reeder, and Peter Wiess for providing technical boat support, and Nick Voichick, Kara Hilwig, and Harlan Taney for providing assistance with field data collection and deployment of thermistor strings.

\section{References Cited}

Blinn, D.W., Shannon, J.P., Stevens, L.E., and Carder, J.P., 1995, Consequences of fluctuating discharge for lotic communities: Journal of the North American Benthological Society, v. 14, no. 2, p. 233-248.

Converse, Y.K., Hawkins, C.P., and Valdez, R.A., 1998, Habitat relationships of subadult humpback chub in the Colorado River through Grand Canyon - spatial variability and implications of flow regulation: Regulated Rivers_-Research and Management, v. 14, no. 3, p. 267-284.

Davis, P.A., 2002, Evaluation of airborne thermal-infrared image data for monitoring aquatic habitats and cultural resources within the Grand Canyon: U.S. Geological Survey Open-File Report 02-367, 49 p., available at http://geopubs.wr.usgs.gov/open-file/of02-367/.

Dolan, R., Howard, A., and Trimble, D., 1978, Structural control of the rapids and pools of the Colorado River in the Grand Canyon: Science, v. 202, no. 4368, doi:10.1126/science.202.4368.629, p. 629631.

Eckhardt, D., 1998, Mapping temperatures of the Colorado and Little Colorado Rivers in the Grand Canyon using airborne thermal sensors: Denver, Colorado, Bureau of Reclamation Technical Service Center Technical Memorandum 8260-98-11, 22 p.

Gloss, S.P., and Coggins, L.G., 2005, Fishes of the Grand Canyon, in Gloss, S.P., Lovich, J.E., and Melis, T.S., eds., The state of the Colorado River ecosystem in Grand Canyon: U.S. Geological Survey Circular 1282, 33-56 p., available at http://pubs.usgs.gov/circ/1282/.

Gorman, O.T., and Stone, D.M., 1999, Ecology of spawning humpback chub, Gila cypha, in the Little Colorado River near Grand Canyon, Arizona: Environmental Biology of Fishes, v. 55, no. 1-2, doi:10.1023/A:1007450826743, p. 115-133.

Hazel, J.E., Jr., Topping, D.J., Schmidt, J.C., and Kaplinski, M., 2006, Influence of a dam on finesediment storage in a canyon river: Journal of Geophysical Research, v. 111, no. F01025, doi:10.1029/2004JF000193, p. 1-16.

Holroyd, E.W., 1995a, Thermal infrared (FLIR) mosaics of the Little Colorado River and FLIR instrumentation: Denver, Colorado, Bureau of Reclamation Technical Service Center Technical Memorandum 8260-95-01, 34 p. 
Holroyd, E.W., 1995b, Temperatures and warm springs along the Little Colorado River: Denver, Colorado, Bureau of Reclamation Technical Service Center Technical Memorandum 8260-95-03, $7 \mathrm{p}$.

Howard, A., and Dolan, R., 1981, Geomorphology of the Colorado River in Grand Canyon: Journal of Geology, v. 89, no. 3, doi:10.1086/628592, p. 269-298.

Kaeding, L.R., and Zimmerman, M.A., 1983, Life history and ecology of the humpback chub in the Little Colorado and Colorado Rivers of the Grand Canyon: Transactions of the American Fisheries Society, v. 112, no. 5, p. 577-594.

Kaplinski, M., 2006, Near shore water temperature data-August 12 to November 14, 2005, data delivery report: Namtek, Inc., submitted to U.S. Geological Survey, Grand Canyon Monitoring and Research Center, cooperative agreement no. 05WRSA0293, 23 p., available at http://www.gcmrc.gov/library/reports/physical/Water_Temperature/Kaplinski2006.pdf.

Kennedy, T.A., and Gloss, S.P., 2005, Aquatic ecology - the role of organic matter and invertebrates, in Gloss, S.P., Lovich, J.E., and Melis, T.S., eds., The state of the Colorado River ecosystem in Grand Canyon: U.S. Geological Survey Circular 1282, p. 87-101, available at http://pubs.usgs.gov/circ/1282/.

Korman, J., Wiele, S.M., and Torizzo, M., 2004, Modeling effects of discharge on habitat quality and dispersal of juvenile humpback chub (Gila cypha) in the Colorado River, Grand Canyon: River Research and Applications, v. 20, no. 4, doi:10.1002/rra.749, p. 379-400.

Korman, J., Kaplinski, M., and Buszowski, J., 2006, Effects of air and mainstem water temperatures, hydraulic isolation, and fluctuating flows from the Glen Canyon Dam on the water temperatures in shoreline environments of the Colorado River in Grand Canyon: Flagstaff, Ariz., Ecometric Research Inc., Northern Arizona University, and Namtek Inc., submitted to U.S. Geological Survey, Grand Canyon Monitoring and Research Center, cooperative agreement no. 04WRAG00006, modification 1, 52 p., available at http://www.gcmrc.gov/library/reports/physical/Water_Temperature/Korman2006b.pdf.

McGuinn-Robbins, D.K., 1995, Comparison of the number and area of backwaters associated with the Colorado River in Glen, Marble and Grand Canyons, Arizona-Draft report: Arizona Game and Fish Department, submitted to Bureau of Reclamation, Glen Canyon Environmental Studies, contract no. 9-FC-40-07940, 26 p., available at http://www.gcmrc.gov/library/reports/physical/hydrology/McGuinn-Robbins1995.pdf.

Parnell, R., Springer, A., and Stevens, L., 1997, Flood-induced backwater rejuvenation along the Colorado River in Grand Canyon, Arizona-1996 final report: Flagstaff, Arizona, submitted to Bureau of Reclamation, Glen Canyon Environmental Studies and Northern Arizona University, 67 p., available at http://www.gcmrc.gov/library/reports/physical/hydrology/Parnell1997.pdf.

Ralston, B.E., 2005, Riparian vegetation and associated wildlife, in Gloss, S.P., Lovich, J.E., and Melis, T.S., eds., The state of the Colorado River ecosystem in Grand Canyon: U.S. Geological Survey Circular 1282, p. 103-121, available at http://pubs.usgs.gov/circ/1282/.

Ralston, B.E., Lauretta, M.V., and Kennedy, T.A., 2007, Comparisons of water quality and biological variables from Colorado River shoreline habitats in Grand Canyon, Arizona, under steady and fluctuating discharges from Glen Canyon Dam: U.S. Geological Survey Open File Report 20071195, 24 p., available at $h t t p: / / p u b s . u s g s . g o v / o f / 2007 / 1195 /$.

Rubin, D.M., Schmidt, J.C., and Moore, J.N., 1990, Origin, structure, and evolution of a reattachment bar, Colorado River, Grand Canyon, Arizona: Journal of Sedimentary Petrology, v. 60, no. 6, p. 982-991. 
Rubin, D.M., Topping, D.J., Schmidt, J.C., Hazel, J., Kaplinski, M., and Melis, T.S., 2002, Recent sediment studies refute Glen Canyon Dam hypothesis: Eos, Transactions, American Geophysical Union, v. 83, no. 25, doi:10.1029/2002EO000191, p. 273, 277-278.

Schmidt, J.C., 1990, Recirculating flow and sedimentation in the Colorado River in Grand Canyon, Arizona: Journal of Geology, v. 98, no. 5, doi:10.1086/629435, p. 709-724.

Schmidt, J.C., and Graf, J.B., 1990, Aggradation and degradation of alluvial sand deposits, 1965-1986, Colorado River, Grand Canyon National Park, Arizona: U.S. Geological Survey Professional Paper 1493, $74 \mathrm{p}$.

Schmidt, J.C., Topping, D.J., Grams, P.E., and Hazel, J.E., Jr., 2004, System-wide changes in the distribution of fine sediment in the Colorado River corridor between Glen Canyon Dam and Bright Angel Creek, Arizona-Final report: Logan, Utah, submitted to U.S. Geological Survey, Grand Canyon Monitoring and Research Center, cooperative agreement no. 1425-98-FC-40-22640, 107 p., available at http://www.gcmrc.gov/library/reports/Physical/Fine_Sed/Schmidt2004.pdf.

Schmidt, J.C., Topping, D.J., Rubin, D.M., Hazel, J.E., Jr., Kaplinski, M., Wiele, S.M., and Goeking, S.A., 2007, Streamflow and sediment data collected to determine the effects of low summer steady flows and habitual maintenance flows in 2000 on the Colorado River between Lees Ferry and Bright Angel Creek, Arizona: U.S. Geological Survey Open-File Report 2007-1268, 79 p., available at http://pubs.usgs.gov/of/2007/1268/.

Stone, D.M., and Gorman, O.T., 2006, Ontogenesis of endangered humpback chub (Gila cypha) in the Little Colorado River, Arizona: American Midland Naturalist, v. 155, no. 1, p. 123-135.

Thomann, R.V., and Mueller, J.A., 1987, Principles of surface water quality modeling and control: Harper and Row, New York, 644 p.

Topping, D.J., Rubin, D.M., and Vierra, L.E., Jr., 2000, Colorado River sediment transport, part 1Natural sediment supply limitation and the influence of the Glen Canyon Dam: Water Resources Research, v. 36, no. 2, p. 515-542.

Topping, D.J., Schmidt, J.C., and Vierra, L.E., 2003, Computation and analysis of the instantaneousdischarge record for the Colorado River at Lees Ferry, Arizona-May 8, 1921, through September 30, 2000: U.S. Geological Survey Professional Paper 1677, 118 p.

Topping, D.J., Rubin, D.M., and Schmidt, J.C., 2005, Regulation of sand transport in the Colorado River by changes in the surface grain size of eddy sandbars over multi-year timescales: Sedimentology, v. 52, no. 5, p. 1,133-1,153.

U.S. Department of the Interior, 1996, Record of Decision, operation of Glen Canyon Dam-Final Environmental Impact Statement: Washington, D.C., Office of the Secretary of the Interior, Bureau of Reclamation, 15 p., accessed on October 13, 2010, at http://www.usbr.gov/uc/rm/amp/pdfs/sp appndxG_ROD.pdf.

U.S. Fish and Wildlife Service, 1994, Final biological opinion on the operation of Glen Canyon Dam as the modified low fluctuating flow alternative of the final environmental impact statement: Albuquerque, N. Mex., consultation no. 2-21-93-F-167, 56 p., available at http://www.grandcanyontrust.org/documents/gc_GlenCanyonOperations.pdf.

U.S. Geological Survey, 2011, Colorado River mileage system: U.S. Geological Survey database, accessed on July 1, 2011 at http://www.gcmrc.gov/dasa/default.aspx.

Valdez, R.A., and Ryel, R.J., 1995, Life history and ecology of the humpback chub (Gila cypha) in the Colorado River, Grand Canyon, Arizona-Final report: Logan, Utah, BIO/WEST, Inc., submitted to Bureau of Reclamation, contract no. 0-CS-40-09110, technical report no. TR-250-08, 328 p., available at http://www.gcmrc.gov/library/reports/biological/Fish_studies/Biowest/Valdez1995f.pdf. 
Vernieu, W.S., Hueftle, S.J., and Gloss, S.P., 2005, Water quality in Lake Powell and the Colorado River, in Gloss, S.P., Lovich, J.E., and Melis, T.S., eds., The state of the Colorado River ecosystem in Grand Canyon: U.S. Geological Survey Circular 1282, p. 69-85, available at http://pubs.usgs.gov/circ/1282/.

Voichick, N., and Wright, S.A., 2007, Water-temperature data for the Colorado River and tributaries between Glen Canyon Dam and Spencer Canyon, northern Arizona, 1988-2005: U.S. Geological Survey Data Series 251, 24 p., available at $h t t p: / / p u b s . u s g s . g o v / d s / 2007 / 251 /$.

Wagner, R.J., Boulger, R.W., Jr., Oblinger, C.J., and Smith, B.A., 2006, Guidelines and standard procedures for continuous water-quality monitors - station operation, record computation, and data reporting: U.S. Geological Survey Techniques and Methods 1-D3, 51 p., available at http://pubs.usgs.gov/tm/2006/tm1D3/.

Wright, S.A., Melis, T.S., Topping, D.J., and Rubin, D.M., 2005, Influence of Glen Canyon Dam operations on downstream sand resources of the Colorado River in Grand Canyon, in Gloss, S.P., Lovich, J.E., and Melis, T.S., eds., The state of the Colorado River ecosystem in Grand Canyon: U.S. Geological Survey Circular 1282, p. 17-31, available at http://pubs.usgs.gov/circ/1282/. 